\title{
Penggenapan Progresif Misi Allah Dalam Kisah Para Rasul 1:8
}

\section{Progressive Fulfillment of God's Mission in Act 1:8}

\author{
Heryanto David Lie ${ }^{1)^{*}}$ \\ 1)Mahasiswa Pascasarjana Prodi Teologi Sekolah Tinggi Theologia Jaffray \\ *)Penulis Korespondensi: heryanto.davidlie@gmail.com
}

\begin{abstract}
Abstrak
Kisah Para Rasul 1:8 merupakan suatu master plan misi Allah yang Kristus amanatkan kepada para murid. Melalui pertolongan dan kuasa Roh Kudus yang telah dicurahkan para peristiwa Pentakosta, seluruh master plan misi Allah tersebut tergenapi secara progresif. Itulah yang hendak Lukas perlihatkan melalui kitabnya yang kedua, Kisah Para Rasul. Kebenaran ini menjadi landasan pemahaman teologis bahwa bermisi adalah melaksanakan master plan misi Allah. Kisah Para Rasul 1:8 juga mengingatkan bahwa menjadi saksi Kristus merupakan panggilan bagi semua orang percaya tanpa terkecuali. Atas dasar kebenaran ini, maka tidak ada alasan bagi orang percaya untuk tidak bermisi atau bersaksi bagi Kristus. Bahkan kebenaran ini mengingatkan bahwa bermisi bukan tergantung kepada hebatnya program tetapi seberapa efektif programprogram tersebut dalam memperkenalkan Kristus. Kisah Para Rasul memberikan suatu dasar kebenaran bahwa pelayanan misi yang dilakukan gerejagereja sekarang sesungguhnya merupakan kelanjutan dari fase "ujung bumi." Misi yang dilakukan oleh gereja-gereja masa kini adalah bagian dari fase memperkenalkan Kristus sampai ke seluruh permukaan bumi secara geografis hingga Kristus kembali untuk kedua kalinya pada akhir zaman.
\end{abstract}

Kata kunci: Master Plan, Allah, Kisah Para Rasul, Kristus, progresif, Roh Kudus.

Acts 1: 8 is a master plan for the mission of God which Christ gave as a mandate to the disciples. Through the help and power of the Holy Spirit that was poured out at the events of Pentecost, the entire master plan of the mission of God is fulfilled progressively. That's what Luke wants to show through his second book, Acts. This truth is the foundation of the theological understanding that missions is carrying out the master plan of God. Acts 1: 8 is also a reminder that becoming a witness of Christ is a call to all believers without exception. On the basis of this truth, then there is no reason for believers not to do missions or witness for Christ. Moreover, this truth is a reminder that doing missions is not dependanton a great program, but on how effective these programs are in introducing Christ. Acts provides a basic truth that missions conducted by churches today is actually a continuation of the phase "ends of the earth." Missions being carried out by the churches of today are part of a phase of introducing Christ to all peopleson the face of the earth until Christ comes again for the second time on the last day.

Keywords: Master Plan, God, Acts, Christ, progressively, Holy Spirit, Luke. 


\section{Pendahuluan}

Kitab Kisah Para Rasul merupakan jilid kedua dari tulisan Lukas. ${ }^{1}$ Secara ekplisit dalam bagian prolog (1:1) Lukas menegaskan bahwa tulisannya tersebut merupakan kelanjutan dari karyanya yang pertama (Injil Lukas). Kedua volume karya Lukas tersebut terlihat memiliki satu kesatuan fokus berita yang sama - keselamatan di dalam Yesus Kristus kepada segala bangsa - serta berkesinambungan. ${ }^{2}$ Injil Lukas dalam narasi kelahiran Kristus melalui seruan malaikat - "Jangan takut, sebab sesungguhnya aku memberitakan kepadamu kesukaan besar untuk seluruh bangsa" (Luk. 2:10) ${ }^{3}$-menekankan siapakah Yesus Kristus yang kisah-Nya dicatat oleh Lukas, yakni Yesus Kristus adalah Juruselamat segala bangsa. Penggenapan dan realisasi berita tersebut ditunjukkan oleh Lukas melalui bukunya yang kedua, Kisah Para Rasul. ${ }^{4}$

Narasi Kisah Para Rasul sendiri dimulai Lukas dengan peristiwa kenaikan Yesus Kristus kembali ke sorga. Yang menarik, peristiwa ini dicatat Lukas di dalam kedua bukunya tersebut (lihat Luk. 24:44-53 dan

${ }^{1}$ Tradisi Kristen mula-mula mengatakan bahwa Injil ketiga dan Kitab Kisah Para Rasul ditulis oleh Lukas (Yuhani Loukas) yang merupakan seorang non-Yahudi yang berbahasa Yunani - yang kemungkinan berasal dari Antiokhia. Lukas diyakini memiliki latar belakang pendidikan medis, yakni seorang dokter. Jelas dia seorang yang berpendidikan. Dan Lukas merupakan kawan seperjalanan dalam perjalanan misi Paulus. Tidak heran ada banyak kata ganti orang pertama jamak ("kami" dalam 16:10-17; 20:5; 21:18; 27:1-28:16) yang dipakai dalam karyanya yang kedua tersebut yang menunjukkan dia terlibat langsung dan menjadi saksi mata, khususnya dalam perjanan misi Paulus. (bandingkan dengan J. N. Geldenhuys, "Lukas, Penulis Injil," dalam Ensiklopedia Alkitab Masa Kini, jilid I (Jakarta: Yayasan Komunikasi Bina Kasih/OMF, 2004), 654.

${ }^{2}$ Witherington III menegaskan, bahwa secara linguistik, gramatikal, tematik, dan teologis tidak terbantahkan Lukas dan Kisah Para Rasul datang dari tangan sama. Lihat Ben Witherington III, The Acts of the Apostles: A Socio-Rhetorical Commentary (Grand Rapids, MI: Wm. B. Eerdmans Publishing Co., 1998), 5. Bandingkan juga dengan John

B. Polhill, "Interpreting the Book of Acts," in Interpreting the New Testament: Essays on Methods and Issues, ed. David Alan Black and David S Dockery (Nashville, Tennessee: Broadman \& Holman Publishers, 2001), 404.

${ }^{3}$ Catatan ini hanya ditemukan dalam Injil Lukas.

${ }^{4}$ Dalam pengamatan Bock, subjek utama Lukas dalam kedua volume tulisannya tersebut bukan hanya tertuju kepada sejarah Yesus Kristus dan gereja-Nya. Beban utama Lukas jauh lebih dalam. Perhatian Lukas kepada rencana Allah yang sedang menggenapi janji-Nya. Awal dari penggenapan tersebut datang melalui Yesus dan Gereja, yang terdiri dari bangsa Yahudi dan bangsa-bangsa lain. Dan akhir dari penggenapan tersebut akan tiba ketika Yesus Kristus datang kembali (Kis. 3:18-26). Lihat Darrell L. Bock, "Teologi Lukas - Kisah Para Rasul," A Biblical Theology of The New Testament (Malang: Gandum Mas, 2011), 95. 
Kis. 1:4-11). ${ }^{5}$ Walau terkesan tumpang tindih, dicatatnya peristiwa kenaikan Yesus Kristus kembali ke Surga di dalam kedua bukunya oleh Lukas menunjukkan adanya nilai penting di balik kisah tersebut, khususnya bagi bukunya yang kedua, Kisah Para Rasul. Peristiwa kenaikan Yesus Kristus dalam bagian prolog Kisah Para Rasul jelas terlihat memiliki kaitan signifikan dengan narasi sepanjang kitab tersebut. Lukas sepertinya hendak menekankan satu pesan, bahwa kembalinya Kristus ke Surga merupakan saatnya bagi para murid melanjutkan misi Yesus dan bergerak untuk memperkenalkan kepada segala bangsa akan Sang Juruselamat dunia. Tekanan misiologis tersebut terlihat dari catatan Lukas tentang amanat Yesus Kristus kepada para murid dalam Kisah Para Rasul 1:8. Secara teologis, amanat Kristus dalam Kisah Para Rasul 1:8 dapat dikatakan sebagai dasar alasanbagi Lukas dalam menghasilkan karya literaturnya yang kedua tersebut. Oleh sebab itu, amanat Yesus Kristus dalam 1:8 dalam kisah kenaikan Yesus Kristus kembali ke Surga memiliki makna penting bagi keseluhuran tulisan Lukas dalam Kisah Para Rasal. Polhill melihat 1:8 yang "sets the theme of the entire book." Lebih dari itu bahkan Lukas menjadikan pasal 1:8 tersebut sebagai dasar dalam membangun struktur kitab Kisah Para Rasul secara keseluruhan. ${ }^{7}$ Melalui pemaparan sebuah perjalanan narasi yang natural Lukas memperlihatkan bagaimana para murid bersaksi tentang Kristus sebagai Juruselamat dunia digenapi secara progresif, mulai dari Yerusalem, menyebar ke daerah Yudea dan Samaria dan akhirnya sampai ke "ujung bumi". Oleh sebab itu, tujuan penulisan ini adalah untuk menunjukkan bagaimana Kisah Para Rasul 1:8 digenapi secara progresif di dalam seluruh kitab Kisah Para Rasul. Selanjutnya, penulis menujukkan beberapa implikasi teologis sebagai implementasi- nya bagi pelayanan misi gereja masa kini.

${ }^{5}$ Paralelisme perikop peristiwa kenaikan Yesus Kristus kembali ke sorga dalam kedua kitab penginjil Lukas hanya akan terlihat ketika pembagian perikopnya keduanya - berbeda dengan pembagian LAI - dimulai dari ayat-ayat yang lebih awal dalam pasalnya masing-masing. Injil Lukas harus dimulai dari ayat 44 (24:44-53) sementara dalam Kisah Para Rasul dimulai dari ayat 4 (1:4-1l). Demikian paralelisme pesan utama kedua perikop akan terlihat lebih jelas. Dalam hal ini, ada pun pesan paralel dari kisah kenaikan Yesus Kristus kembali ke sorga dalam kedua kitab tersebut adalah amanat Yesus Kristus kepada para murid sebelum terangkat ke sorga agar mereka pergi menjadi saksi-Nya bagi bangsa-bangsa.

${ }^{6}$ Polhill, "Interpreting the Book of Acts," 404.

${ }^{7}$ I. Howard Marshall, The Acts of The Apostles: An Introduction and Commentary, Tyndale New Testament Commentaries (Nottingham, England \& Surabaya, Indoneseia: InterVarsity Press \& Momentum, 2007), 61. 


\section{Analisis Biblika terhadap Kisah Para Rasul 1:8 dan Penggenapannya}

Kisah Para Rasul 1:8 memiliki peranan penting dalam membentuk struktur dan alur pikiran Lukas dalam seluruh kitab Kisah Para Rasul. Ayat ini menjadi dasar berpijak Lukas dalam menyampaikan pesan dari kitab ini bahwa sejarah gereja mula-mula membuktikan apa yang diamatkan Kristus kepada para murid-Nya telah terlaksanakan dan tergenapi secara progresif.

\section{Analisis Konteks Kisah Para Rasul 1:8}

Literatur Helenistik menunjukkan karya atau tulisan dengan genre "Acts" umumnya mencatat perbuatan-perbuatan dari satu peribadi yang terkenal, seperti Aleksander Agung, Augustus dan tokoh-tokoh besar lainnya. Namun adakalanya juga berupa catatan tentang sekelompok orang terkenal, seperti The Acts of Early Kings. ${ }^{8}$ Dalam hal ini, dalam perspektif genre Acts atau Kisah Para Rasul dapat dikatakan sebagai sebuah catatan tentang perbuatan satu pribadi tertentu atau mungkin catatan yang berisi perbuatan dari sekelompok orang atau bahkan keduanya.

Pada abad ke-2 dan ke-3, Bapa-bapa gereja mulai coba memberi judul bagi buku Lukas yang kedua tersebut, karena Lukas sendiri tidak memberikan judul baginya. Beberapa judul yang pernah diusulkan seperti, The Memorandum of Luke oleh Tertullianus, The Acts of All the Apostles oleh kanon Muratorian. Dan yang paling terkenal The Acts of the Apostles, yang pertama kali dipakai dalam pengantar kepada Lukas oleh anti-Marcionite dan juga oleh Irenius ${ }^{9}$-akhirnya judul ini juga yang dipakai dalam terjemahan LAI yang diterjemahkan sebagai Kisah Para Rasul.

Jikalau memerhatikan isi dari pada kitab ini, maka sesungguhnya yang hendak ditunjukkan oleh Lukas bukanlah keberhasilan para rasul dalam melaksanakan amanat Kristus. Dengan kata lain bukan kehebatan para murid yang hendak diperlihatkan, melainkan karya dan kuasa Roh Kudus dalam menuntun dan memampukan sehingga misi Kristus yang dititipkan kepada murid-murid-Nya terlaksana dengan sempurna. Roh Kudus di dalam kuasa-Nyalah yang memimpin para murid untuk bersaksi sampai akhirnya secara bertahap menggenapkan amanat Kristus tersebut. Dalam hal ini, Witherington III memberikan satu kesimpulan yang sangat baik, "If there is any dominant actor in the book of Acts,

${ }^{8}$ Darrell L. Bock, Acts, Baker Exegetical Commentary on the New Testament (Grand Rapids, MI: Baker Academic, 2007), 1.

${ }^{9}$ D. A. Carson dan Douglas J. Moo, An Introduction to the New Testament, second edition (Grand Rapids, Michigan: Zondervan, 2005), 285. 
it is God in the person of the Holy Spirit who guides and directs the words and deeds especially of the main protagonists in the narrative." ${ }^{10}$ Oleh sebab itu, sebenarnya judul yang tepat diberikan bagi buku kedua dari Lukas ini adalah "The Acts of the Holy Spirit". ll Bruce (1990:21-22) sebagaimana dikutip Bock menyebutnya sebagai Gospel of the Holy Spirit. ${ }^{12}$ Klein bersama koleganya, Blomberg dan Hubbard, Jr. dalam Introduction to Biblical Interpretation melihat judul ini lebih deskriptif karena sejalan dengan pemaparan Lukas tentang turunnya Roh Kudus di hari Pentakosta dan dilanjutkan dengan pemenuhan-Nya atas diri orang-orang percaya sebagai kunci dari kelahiran dan pertumbuhan komunitas Kristen yang baru. ${ }^{13}$

Sebaliknya, ada kesan kurang tepat kalau kitab ini diberi judul The Acts of the Apostles karena Kisah Para Rasul sendiri tidak mengisahkan seluruh rasul yaitu duabelas rasul. Hanya dua orang yang menonjol dari kelompok ini dalam tulisan Lukas, yakni Petrus dan Yohanes. Selanjutnya orang-orang kunci lainnya yang dicatat Lukas dalam kitab ini justru bukan dari kelompok ini. Stefanus, Filipus, ${ }^{14}$ Paulus dan Yakobus (saudara Tuhan Yesus) ${ }^{15}$ serta Barnabas merupakan tokoh-tokoh di luar

\footnotetext{
${ }^{10}$ Witherington III, The Acts of the Apostles, 21.

${ }^{11}$ Bandingkan dengan Carson dan Moo, An Introduction to the New Testament, 285.

${ }^{12}$ Bock, Acts, 2.

${ }^{13}$ William W. Klein, Craig L. Blomberg, Robert L. Hubbard, Jr., Introduction to Biblical
} Interpretation 2: Pengantar Tafsiran Alkitab (Malang: SAAT, 2013), 368.

${ }^{14}$ Nama Filipus dalam Kisah Para Rasul merujuk kepada dua orang yang berbeda, yakni Filipus satu dari dua belas rasul (1:13) dan Filipus satu dari tujuh diaken (6:5). Filipus yang dicatat Lukas dalam pasal 8 dan seterusnya adalah Filipus diaken, bukan rasul. Dalam 8:1 dicatat bahwa ketika terjadi penganiayaan di Yerusalem, orang-orang percaya menyebar ke daerah Yudea dan Samaria, sementara para rasul tetap bertahan. Dengan demikian, maka jelas Filipus yang berangkat ke Samaria dan memberitakan Injil di sana adalah Filipus diaken. Bandingkan dengan Marshall, The Acts of The Apostles, 154.

${ }^{15}$ Nama Yakobus dalam Kisah Para Rasul juga merujuk kepada lebih dari satu orang, yakni rasul dan saudara Tuhan Yesus. Bahkan dari dua belas murid sendiri ada dua yang bernama Yakobus, yakni Yakobus saudara Yohanes (12:2) dan Yakobus bin Alfeus. Namun untuk kedua Yakobus yang berasal dari rasul-rasul oleh Lukas sudah diberi perbedaan yang cukup jelas. Lalu siapakah Yakobus yang beberapa kali disebutkan Lukas yang kelihatannya mempunyai pengaruh yang besar dalam jemaat Yerusalem? Lukas mencatat bahwa Yakobus saudara Yohanes telah mati syahid dalam 12:2. Maka kelihatannya jelas, nama Yakobus - karena tanpa penyebutan "bin Alfeus" - adalah Yakobus saudara Tuhan Yesus. Kehormatan yang diberikan oleh orang percaya termasuk para rasul kepada Yakobus - bahkan dia diyakini sebagai pemimpin jemaat Yerusalem (terlihat dari tindakannya saat mengambil keputusan dalam sidang Yerusalem dalam 15:13) - mungkin karena statusnya sebagai saudara Tuhan Yesus. Tentu ini bukanlah satu-satunya alasan dia diangkat menjadi pemimpin jemaat Yerusalem. Dari tindakannya ketika sidang Yerusalem yang pertama (15:13-21) menunjukkan memang dia memiliki kapabilitas sebagai seorang pemimpin. Hegesipus, 
dua belas murid yang ikut ditonjolkan oleh Lukas dalam Kisah Para Rasul. ${ }^{16}$ Kalaupun judul The Acts of the Apostles tetap dipakai, sebagaimana dijelaskan Bock,

.... was intended to highlight that the characters God uses in Acts are to be seen as sent from God. Acts, however, is less focused on individuals than it is on the selective presentation of the growth of the community and its message... In fact, the key character in Acts is God, his activity, and his plan.17

Dalam konteks Kisah Para Rasul, amanat Yesus Kristus dalam 1:8 sendiri merupakan bagian dari pernyataan-Nya sebagai respons kepada pertanyaan para murid dalam 1:6: "Lord, are you at this time going to restore the kingdom to Israel?" (NIV). ${ }^{18}$ Namun pertanyaan para murid sendiri muncul karena pernyataan Yesus dalam ayat 5 yang menegaskan bahwa mereka tidak lama lagi ${ }^{19}$ akan dibaptis dengan Roh Kudus. Kata chronō, dari kata chronos yang secara literar dapat diartikan "time" dalam pertanyaan para murid merujuk kepada a specific interval of time, yakni the specific interval of time of the restoration of Israel's Kingdom. Dalam literatur Yahudi termasuk yang di luar Perjanjian Lama, harapan bahwa Israel akan dipulihkan kembali menjadi "a place of great blessing" mendapat perhatian penting terkhusus sejak pembuangan (bdg. Yer. 16:15; 23:8; 31:27-34; Yeh. 34-37; Yes. 2:2-4; 49:6; Amos 9:11-15; Sirakh 48:10; Kebijaksanaan Salomo 17-18; 1 Henokh 24-25; Tobit 13-14). ${ }^{20}$ Sementara pencurahan Roh Allah ke atas umat-Nya dalam konteks literatur Yahudi (khususnya Perjanjian

dalam catatan sejarah, menyebutnya sebagai seorang yang saleh dan jujur (Eus., EH. 2. 23). Bahkan tradisi mengatakan bahwa Tuhan Yesus sendirilah yang menunjuknya menjadi uskup pertama di Yerusalem (Eus., EH. 7. 19). Lihat Marshall, The Acts of The Apostles, 210-21l; bandingkan dengan R. V. G. Tasker, "Yakobus," dalam Ensiklopedia Alkitab Masa Kini, jilid II (Jakarta: Yayasan Komunikasi Bina Kasih/OMF, 2004), 546.

${ }^{16}$ Bock, Acts, 2.

17 Bock, Acts, 1 .

${ }^{18}$ Terjemahan LAI - "Tuhan, maukah Engkau pada masa ini memulihkan kerajaan bagi Israel?" mengindikasikan bahwa para murid sedang mengajukan permintaan bukan pertanyaan. Sementara melihat respons Yesus dalam pada 1:7, maka seharusnya apa yang diajukan para murid adalah pertanyaan bukan permintaan/permohonan. Dalam hal ini beberapa terjemahan Inggris menerjemahkannya dengan lebih tepat, seperti NIV (yang dikutip di atas), NET Bible "Lord, is this the time when you are restoring the kingdom to Israel?", KJV "Lord, wilt thou at this time restore again the kingdom to Israel?", NAS "Lord, is it at this time You are restoring the kingdom to Israel?".

${ }^{19}$ NET Bible menerjemahkan frasa "tidak lama lagi" dengan "not many days from now".

${ }^{20}$ Lihat Bock, Acts, 61. 
Lama) diyakini sebagai tanda datangnya zaman baru tersebut, yakni dimulainya chronos restorasi Israel (Yoel 2:28; bdg. 2:18; 3:1). ${ }^{21}$ Tentu ini menjadi peluang naiknya ekspektasi mereka akan tibanya chronos restorasi Israel.

Selanjutnya jika mundur lagi pada ayat 4, akan ditemukan catatan Lukas tentang nasihat Yesus kepada para murid-Nya supaya tidak meninggalkan Yerusalem. Yesus secara tegas menyarankan para murid untuk tidak meninggalkan Yerusalem karena janji pencurahan Roh Kudus akan segera terjadi di sana. Dan tentu tidak diragukan bahwa para murid memiliki dasar pengetahuan akan pengajaran Perjanjian Lama bahwa harapan restorasi Israel akan dimulai di Yerusalem. ${ }^{22}$ Pada kesempatan yang sama, keyakinan para murid akan kemesiasan Yesus Kristus juga pasti tidak terbantahkan. Dalam hal ini yang diyakini telah diteguhkan oleh kebangkitan Yesus Kristus sendiri. Maka tidak heran, dengan dasar harapan mesianik yang tinggi kepada Yesus Kristus yang mereka miliki, ketika para murid mendengar Yesus berbicara tentang kedatangan Roh Kudus yang tidak lama lagi akan terjadi di Yerusalem, maka fokus mereka langsung tertuju kepada restori kerajaan Israel. ${ }^{23}$ Peterson menegaskan, "The apostles were expecting Jesus, as God's anointed king, to usher in the restoration to which many Jews looked forward, and of which Jesus himself had spoken." 24 Ini memperlihatkan harapan politis akan restorasi Israel masih sangat kental dalam pemikiran para murid. Bruce mengatakan, "The apostles evidently maintained their interest in the hope of seeing the kingdom of God realized in the restoration of Israel's national independence." 25

Tanggapan Yesus dalam ayat 7 menunjukkan bahwa Dia memang tidak menyanggah secara langsung ekspektasi politis akan restorasi kerajaan Israel dari para murid tersebut. Yesus justru mengakui bahwa memang masa itu akan terjadi. Namun, dengan terkesan sedikit

${ }^{21}$ Bandingkan dengan David J. Williams, New International Biblical Commentary: Acts (Peabody, MA: Hendrickson Publishers, 1990), 23.

22 Secara politis memang restorasi harus di mulai dari Yerusalem, karena menjadi pusat pemerintahan. Di samping itu, secara teologis, keberadaan Bait Suci dalam kota Yerusalem menjadi alasan penting akan kepentingannya sebagai pusat terjadinya restorasi. Dan yang dasar pamahaman teologis terpenting akan Yerusalem sebagai pusat terjadinya restorasi Israel adalah nubuatan para nabi dalam PL (bdg. Yes. 2:2-4; Mi. 4:18; Zak. 8:20-23). Bandingkan dengan David G. Peterson, The Acts of the Apostles, The Pillar New Testament Commentary (Grand Rapids, MI: Wm B. Eerdmans Publishing Co., 2009), 109.

${ }^{23}$ F. F. Bruce, The Book of the Acts, The New International Commentary on the New Testament (Grand Rapids, MI: Wm. B. Eerdmans Publishing Co., 1988), 35.

${ }^{24}$ Peterson, The Acts of the Apostles, 109.

${ }^{25}$ Bruce, The Book of the Acts, 35. 
spekulatif, Yesus menjelaskan bahwa masa itu merupakan sebuah "rahasia ilahi". Jawaban Yesus tersebut secara tidak langsung menegas- kan bahwa waktu atau masa itu masih menjadirahasia eskatologis yang ada dalam kedaulatan Bapa tentang waktu penggenapannya. Bahkan Anak sendiri pun tidak tahu mengenai kapan waktunya tersebut akan tiba (bdg. Mrk. 13:32). ${ }^{26}$ Jawaban Yesus sebenarnya sedang merujuk "waktu" atau "masa" kepada final restotarion of Israel. Yang menarik kata "waktu" atau "masa" (chronous $\bar{e}$ kairous) ${ }^{27}$ dalam jawaban Yesus dalam bentuk jamak. Menanggapi hal ini, Bock menegaskan, "The question about the specific time in verse 6 is answered with respect to all times and seasons in verse 7." ${ }^{28}$ Yesus sedang membawa para murid kepada suatu pemahaman bahwa mengenai "waktu" atau "masa" memang tidak dapat ditebak. Hal ini tentu sejalan dengan penegasan Yesus bahwa itu adalah sebuah rahasia Ilahi. Marshall menjelaskan, kalau itu merupakan rahasia Allah, maka tidak ada tempat bagi manusia untuk berspekulasi. ${ }^{29}$ Inti jawaban Yesus tentang penggenapan "waktu" atau "masa" - secara tidak langsung- adalah bahwa waktu itu memang belum tiba. Dengan kata lain, jawaban Yesus atas pertanyaan para murid dalam ayat 6 adalah "bukan". Hanya saja, sebagaimana pandangan Bruce, "Jesus' answer did not take the form of a direct "No."'30

Namun pada sisi lain, penekanan Yesus tentang kedatangan Roh Kudus yang tidak lama lagi memberi indikasi kuat akan ada sesuatu yang baru yang akan segera terjadi. Dalam pengajaran-Nya sebagaimana yang Lukas coba perlihatkan dalam ayat 3 bahwa kebenaran tentang Kerajaan Allah (tēs basileias tou theou) $)^{31}$ menjadi berita utama Yesus. Fokus berita tulisan Lukas sendiri - baik Injil Lukas maupun Kisah Para Rasul tentang keselamatan di dalam Yesus Kristus bagi segala bangsa tidak bisa dilepas dari penekanan teologisnya tentang Kerajaan Allah. Dalam

${ }^{26}$ Bruce, The Book of the Acts, 35.

${ }^{27}$ Pertanyaan para murid dalam ayat 6 hanya menggunakan kata " $\chi \rho o ́ v o \varsigma$ " untuk merujuk kepada datangnya masa pengharapan Israel, sementara Yesus dalam ayat 7

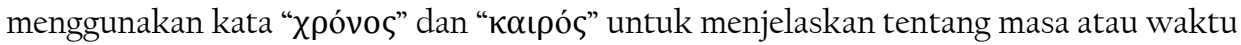
tersebut. Namun kata "ฑ" yang digunakan dalam jawaban Yesus, sepertinya mensejajarkan kedua kata tersebut. Dalam pengamatan Bock, "It is possible, however, that the first refers to a specific time period and the second to a broader time frame." Lihat Bock, Acts, 63.

${ }^{28}$ Bock, Acts, 63; Tulisan Bock berdasarkan pemahaman Jervell (1998:115).

${ }^{29}$ I. Howard Marshall, The Acts of The Apostles: An Introduction and Commentary, Tyndale New Testament Commentaries (Nottingham \& Surabaya: Inter-Varsity Press \& Momentum, 2007), 60.

${ }^{30}$ Bruce, The Book of the Acts, 35.

${ }^{31}$ Dalam Kisah Para Rasul, kata "Kerajaan Allah" (tēs basileias tou theou) muncul sebanyak enam kali (1:3; 8:12; 14:22; 19:8; 28:23, 31). 
bukunya yang pertama Lukas memulai narasi kelahiran Yesus dengan memberi penekanan akan kedatangan Yesus Kristus sebagai Raja dari keturunan Daud (bdk. Luk. 1:27, 32-33, 68-69; 2:4, 11). Dan di dalam bukunya yang kedua, seperti yang dikatakan Goldsworthy, “...Luke's account of how the kingdom comes by the preaching of the gospel in all the world (Acts 1:6-8;2:22-36)." "32 Lukas memulai Kisah Para Rasul dalam 1:3 dengan catatan bahwa berita utama Yesus setelah kebangkitan-Nya sampai menjelang kenaikan-Nya adalah tentang Kerajaan Allah, serta menutup kitab keduanya tersebut dengan catatan tentang pemberitaan rasul Paulus ketika dia berada di Roma juga tentang Kerajaan Allah (28:30-31). ${ }^{33}$ Lukas ingin menunjukkan bahwa berita tentang Kerajaan Allah memiliki signifikansi teologis yang penting atas kesaksian para murid dalam Kisah Para Rasul.

Bock melihat, "God's Kingdom... refers to God's promised rule that comes with Jesus's messianic program and activity." ${ }^{4}$ Yesus Kristus membangun Kerajaan Allah tersebut melalui diri-Nya dan dengan diri-Nya sendiri bertindak sebagai Raja di dalam-Nya (bdg. Luk. 1:33; Yes. 9:5-6). Di dalam pelayanan-Nya, Yesus menunjukkan tanda-tanda bahwa Kerajaan tersebut telah datang (bdg. Luk. 1l:20; 17:21). Kerajaan Allah itu sendiri telah hadir bersama dengan kedatangan Yesus Kristus, Sang Mesias. Namun kehadiran Roh Kudus diperlukan untuk meneguhkan akan datangnya Kerajaan tersebut, dan sekaligus untuk memetraikan umatNya yang akan masuk ke dalamnya. Di samping itu pencurahan Roh Kudus merupakan penanda titik balik yang krusial dari zaman perjanjian Musa (Kovenan Lama) menuju zaman perjanjian baru (Kovenan Baru) yang dihasilkan melalui kematian Yesus Kristus yang memberi landasan, dengan kebangkitan-Nya yang membenarkan dan meneguhkan, serta kenaikan-Nya ke surga untuk duduk di sebelah kanan Bapa bertakhta sebagai Raja (1:1-11). ${ }^{35}$ Baptisan dan didiaminya semua orang percaya oleh Roh Kudus (2:38-39; bdg. 1 Kor. 12:13) dan fenomena bahasa-bahasa asing (2:5-12;10:44-46;19:4-7) menandai sebuah pemisahan yang signifikan dari masa-masa Perjanjian Lama. ${ }^{36}$

Yesus sedang memproklamirkan Kerajaan-Nya, Kerajaan Allah. Dan kehadiran Roh Kudus yang tidak lama lagi akan segera meneguhkannya.

32 Graeme Goldsworthy, "The Kingdom of God as Hermeneutic Grid," Southern Baptist Journal of Theology 12/1 (Spring 2008):13.

${ }^{33}$ Bandingkan dengan Todd L. Miles, "A Kingdom without a King? Evaluating the Kingdom Ethic(s) of the Emerging Church," Southern Baptist Journal of Theology 12/1 (2008):90.

${ }^{34}$ Bock, Acts, 55.

${ }^{35}$ Klein, Blomberg, Hubbard, Jr., Introduction to Biblical Interpretation 2, 375.

${ }^{36}$ Klein, Blomberg, Hubbard, Jr., Introduction to Biblical Interpretation 2, 376. 
Namun Kerajaan yang Dia bawa memiliki pemahaman yang berbeda dengan apa yang diharapkan para murid atas-Nya. Jawaban Yesus dalam 1:8 yang sekaligus sebagai amanat-Nya kepada para murid-Nya sedang mengarahkan para murid-Nya kepada pemahaman baru terhadap konsep Kerajaan-Nya. Seperti yang dijelaskan Peterson, Yesus “...interpreted it in terms of the gift of the Spirit and the fulfillment of prophecies about the restoration of Israel as a servant community, called to be God's 'witnesses' to the nations (Is. 43:10, 12 and 44:8)." 37

Masa restorasi itu memang akan dimulai melalui hadirnya Roh Kudus ke tengah-tengah umat-Nya. Sebagaimana kelanjutan penjelasan Perterson, "The end-time restoration would begin with the pouring out of the promised Spirit and the bringing of God's salvation, first to Israel and then 'to the ends of the earth' (Is. 49:6; cf. Is. 42:6-7). It would be consummated when Jesus returned (cf. 1:11; 3:20-21)." 38 Namun restorasi yang terjadi sejak hadir-nya Roh Kudus bersifat telah terjadi tetapi masih menanti penyempurnaannya pada saat kedatangan Yesus Kristus yang kedua kali kembali pada akhir zaman. Peterson menambahkan, "Through the witness of Jesus' apostles, 'the kingdom' would be restored to Israel, but not in nationalistic or political terms, nor immediately in the full and final sense outlined in biblical prophecy (cf. 3:19-26)." ${ }^{39}$ Itulah Kerajaan yang Kristus bangun, bukan dalam pengertian politis apalagi geografis. Dengan kata lain, restorasi Kerajaan Israel yang dimulai dan dipimpin Yesus Kristus adalah secara rohani. Suatu kerajaan yang menuntut orang-orang yang hidup di dalam pimpinan Roh Kudus ${ }^{40}$ dan bersaksi bagi Kristus untuk membawa jiwajiwa (bangsa-bangsda) masuk ke dalam Kerajaan-Nya tersebut. Marshall menjelaskan, hal yang perlu dilakukan oleh para murid adalah menyelesaikan tugas mereka sebagai saksi Kristus, bukan terfokus pada apocalyptic speculation. ${ }^{41}$

Janji Kuasa untuk Bersaksi dari Roh Kudus

"Tetapi kamu akan menerima kuasa, kalau Roh Kudus turun ke atas kamu." Jawaban Yesus dalam ayat 8 dapat dikatakan sebagai suatu

${ }^{37}$ Peterson, The Acts of the Apostles, 109. ${ }^{38}$ Peterson, The Acts of the Apostles, 109. ${ }^{39}$ Peterson, The Acts of the Apostles, 109.

${ }^{40}$ Kerajaan Allah dalam pengajaran Yesus oleh mayoritas ahli Perjanjian Baru dewasa ini lebih dipahami sebagai pemerintahan Allah dari pada wilayah kekuasaanNya, tepatnya pemerintahan Allah atas hidup umat-Nya. Lihat John Drane, Memahami Perjanjian Baru: Pengantar Historis-Teologis (Jakarta: BPK Gunung Mulia, 2005), 128-129.

${ }^{41}$ I. Howard Marshall, The Acts of The Apostles: An Introduction and Commentary, Tyndale New Testament Commentaries (Nottingham \& Surabaya: Inter-Varsity Press \& Momentum, 2007), 60. 
pengalihan fokus dari hal yang kurang penting kepada hal yang lebih penting. Hal ini dipertegas oleh penggunaan kata konjungsi "tetapi" $(\dot{\alpha} \lambda \lambda \grave{\alpha}$, alla). Kata "tetapi" mengarahkan perhatian para murid kepada kuasa Roh Kudus yang akan turun untuk memampukan mereka untuk menjadi saksi-saksi Kristus. Sebelum masa penyempurnaan restorasi "Israel" tiba, sebagaimana dijelaskan di atas, tugas utama yang perlu dilakukan dan diselesaikan oleh murid-murid Tuhan adalah menjadi saksi bagi-Nya. ${ }^{42}$ Namun sebelum mereka menjalankan mandat Yesus tersebut, mereka harus menerima kuasa melalui pencurahan Roh Kudus yang akan terjadi tidak lama lagi.

Kata "kuasa" berasal dari kata dunamin dari akar kata dunamis yang secara literal berarti, power, might, strength, force (Mat. 14:2; 22:29; Kis. 1:8; Rom. 1:4; Kol. 1:11; 2 Tim. 3:5; Ibr. 7:16; 2 Pet. 1:3). Secara sederhana dunamis dapat diartikan suatu kekuatan, kuasa, kemampuan yang memungkin sesuatu untuk dilakukan atau diselesaikan. Dalam konteks ini, berarti dengan dunamis dari Roh Kudus para murid akan dimampukan, diperlengkapi untuk bersaksi. Peterson menjelaskan, "the power that is promised in 1:8 is essentially related to the task of being Christ's witnesses, though this is not all that Acts teaches about the role of the Spirit in believers." ${ }^{43}$ Bahkan dunamis dari Roh Kudus akan menjadi kekuatan bagi para murid Kristus untuk mendobrak segala halangan dan rintangan dalam bersaksi.

Kata dunamis digunakan oleh Lukas dalam Kisah Para Rasul sebanyak sepuluh kali dengan beberapa konteks pemakaian. ${ }^{44}$ Tiga kali (2:22; 8:13; 19:11) yang merujuk kepada kuasa dalam mukjizat-mukjizat; tiga kali untuk menjelaskan tentang kuasa yang menyebabkan terjadinya mukjizat-mukjizat (3:12; 4:7; 10:38). Dua kali merujuk kepada kuasa yang menyertai perbuatan para rasul (4:33) dan Stefanus (6:8) seperti dalam perkataan mereka dan juga termasuk perbuatan mukjizat yang mereka lakukan. Sementara 8:10 merujuk kepada kuasa di balik perbuatan sihir seorang yang bernama Simon si tukang sihir. Dan yang terakhir, yang dapat dikatakan yang terpenting - yang kelihatannya Lukas hendak merujuk semua pemakaian dunamis dalam Kisah Para Rasul pada bagian ini adalah 1:8. Barrett menegaskan, "This last reference contributes nothing, but

${ }^{42}$ Ben Witherington III, The Acts of the Apostles: A Socio-Rhetorical Commentary (Grand Rapids, MI: Wm. B. Eerdmans Publishing Co., 1998), 110.

${ }^{43}$ Peterson, The Acts of the Apostles, 110.

${ }^{44}$ Lihat Bock, Acts, 63. Bandingkan dengan C. K. Barrett, A Critical and Exegetical Commentary on the Acts of the Apostles (Edinburgh: T\&T Clark International - The International critical commentary on the Holy Scriptures of the Old and New Testament, 2004) 78 . 


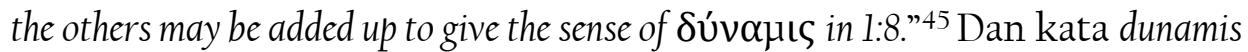
itu sendiri hanya akan didapatkan kalau Roh Kudus turun ke atas mereka. Oleh sebab itu, Yesus sebagaimana dicatat Lukas dalam ayat 4 telah mengingatkan mereka supaya tidak meninggal-kan Yerusalem untuk menanti kedatangan Roh Kudus (1:5 bdg. Luk. 24:49). Dalam ayat 4, Lukas menghubungkan Roh Kudus sebagai Pribadi yang dijanjikan oleh Bapa yang akan memberikan kuasa bagi orang percaya (bdg. Luk. 24:29; Kis. 2:17-21; dan perhatikan Yoel 2:28-32). Dan di dalam Kisah Para Rasul, Lukas secara historis membuktikan bagaimana Pribadi tersebut berkarya membangun gereja-gereja-Nya melalui para penginjil. Barrett mengeaskan, "The Holy Spirit is one of the major themes of Acts; some would say the central and most important theme." 46 Ini menjadi alasan kuat mengapa Lukas menggunakan bagian prolog ini untuk memperkenalkan Roh Kudus yang secara profetik telah dijanjikan Bapa akan segera datang. Pasal 2 mencatat secara detail bagaimana janji Bapa tersebut digenapi secara supernatural melaui peristiwa Pentakosta - pencurahan Roh Kudus (2:1-13). ${ }^{47}$ Sejak itu secara tidak langsung, Lukas memperlihatkan bagaimana Roh Kudus bekerja di balik pribadi-pribadi yang diurapi-Nya pasal demi pasal yang dimulai dari rasul Petrus di dalam khotbahnya yang telah mempertobatkan kira-kira tiga ribu orang (2:14-41). Kuasa Roh Kudus juga diperlihatkan bekerja di dalam kehidupan komunitas orang percaya. Inilah signifikansi peran dan karya Roh Kudus dalam pembangunan Kerajaan Allah yang hendak diperlihatkan Lukas dalam Kisah Para Rasul.

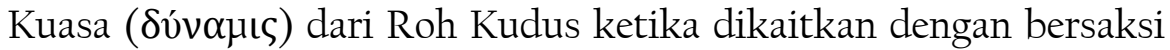
( $\mu$ ó $\rho \tau u \rho \varepsilon \varsigma$, martures) bagi Bock mempunyai pengertian "to being empowered to speak boldly by testifying to the message of God's work through Jesus." ${ }^{8}$ Kuasa Roh Kudus dalam bersaksi bukan hanya berbicara tentang keberanian, namun juga harus dipahami sebagai pemberian hikmat oleh Roh Kudus kepada para penginjil dalam bersaksi misalnya Stefanus dengan penuh

${ }^{45}$ Barrett, A Critical and Exegetical Commentary on the Acts of the Apostles; The Acts of the Apostles, 78 .

${ }^{46}$ Barrett, A Critical and Exegetical Commentary on the Acts of the Apostles; The Acts of the Apostles, 111.

47 Terkait dengan peristiwa pencurahan Roh Kudus dalam 2:1-13, Peterson menegaskan, "The Holy Spirit's 'coming' is not continuous, but definitive (the context so delimits the aorist participle epelthontos to show that the meaning is temporal and punctiliar here), though clearly the Spirit is available at any time after Pentecost for those who repent and are 'baptized in the name of Jesus Christ' (2:38). In the light of v. 5, this coming of the Spirit upon the apostles must be equivalent to being baptized with the Holy Spirit (cf. 2:4 note)." Lihat Peterson, The Acts of the Apostles, 110.

${ }^{48}$ Bock, Acts, 63. 
hikmat dari Roh Kudus melakukan pembelaan di hadapan imam besar (7:1-53). Kuasa Roh Kudus dalam Kisah Para Rasul juga berkaitan erat dengan karunia Allah, yakni kemampuan dalam melakukan tanda-tanda dan mukjizat sebagai bukti peneguhan datangnya zaman baru atau kovenan baru, lebih tepatnya Kerajaan Allah.

"Bersaksi" ( $\mu \alpha \alpha \rho \tau u \rho \varepsilon s$, martures) ${ }^{49}$ sebenarnya bukan konsep baru dalam era kovenan baru. Konsep ini memiliki akar dalam Perjanjian Lama (Bil. 35:30; Ul. 17:6-7; Yes. 43:10-12; 44:8). ${ }^{50}$ Pentateukh merujuk kata "saksi" (Ibrani êd) ke dalam konteks yustisi, yakni saksi dalam sebuah pengadilan. Sementara dalam Yesaya merujuk kepada saksi Allah. Catatan dalam Yesaya 43:10-12 ${ }^{51}$ sekalipun bagian ini mengandung makna profetik - memberi bukti bahwa bangsa Israel sebenarnya telah diamanatkan oleh Allah akan panggilan untuk menjadi saksi Allah, bahkan dari sejak panggilan pertama kali datang kepada Abraham (bdk. Kej. 12:2-3). Namun umat kovenan lama gagal menjalankan panggilan Allah tersebut, khususnya mereka gagal untuk menjadi saksi Allah bagi bangsa-bangsa lain. Dan panggilan ini dialamatkan kembali kepada umat kovenan baru. Bahkan Kisah Para Rasul 1:8 memperlihatkan, menjadi saksi Kristus merupakan panggilan utama umat kovenan baru.

Para murid dipanggil untuk menjadi saksi bagi Kristus, berarti modal mereka dalam bersaksi adalah pengalaman mereka tentang kebersamaan dengan Yesus Kristus. Lukas menegaskan bahwa modal utama para murid dalam bersaksi adalah apa yang mereka saksikan dengan mata mereka tentang Yesus Kristus, khususnya tentang kebangkitan-Nya (bdg. Luk. 24:48; 1:22). ${ }^{52}$ Bahkan dapat dipastikan bahwa inilah tujuan utama dari Lukas lewat bukunya, Kisah Para Rasul, sebagai kesaksian tertulis tentang siapakah Yesus Kristus, Sang Mesias yang hidup, dan bagaimana kesaksian itu secara dinamis diteruskan para penginjil sampai ke ujung bumi.

Roh Kudus yang memberi mereka kapabilitas untuk dapat bersaksi dengan berani dan penuh kuasa. Secara tidak langsung Lukas dalam pasal 2 memperlihatkan bagaimana Petrus seorang yang pernah menyangkal Yesus sebanyak tiga kali diubahkan dan dimampukan

${ }^{49}$ Kata "Bersaksi" ( $\mu \alpha \dot{\rho} \rho \tau u \rho \varepsilon \varsigma$, martures) muncul sebanyak tiga belas kali dalam Kisah Para Rasul dari tiga puluh lima kali pemunculan dalam seluruh Perjanjian Baru. Lihat Bock, Acts, S. 64.

${ }^{50}$ Bock, Acts, 63.

${ }^{51}$ Frasa 'you will be my witnesses' (esesthe mou martyres) paralel dengan Yesaya 43:10 (bdk. 43:12, hymeis emoi martyres; 44:8). Peterson menjelaskan, "Isaiah envisages that the renewed people of God will be witnesses to the nations of the salvation of God when the new age arrives." Lihat Peterson, The Acts of the Apostles, 111.

${ }^{52}$ Bandingkan dengan Bock, Acts, 64. 
menjadi seorang saksi Kristus yang efektif yang berhasil mempertobatkan kira-kira tiga ribu jiwa dalam sekali berkotbah. ${ }^{53}$

Yang menjadi pertanyaan, bagaimana dengan Paulus, Stefanus, Filipus dan yang lainnya yang bukan berasal dari dua belas murid? ${ }^{54}$ Apakah mereka memiliki kualifikasi sebagai saksi-saksi Kristus? Melalui Kisah Para Rasul, Lukas justru memperlihatkan mereka sebagai saksisaksi Kristus yang hebat. Sekalipun mereka tidak menjadi saksi mata langsung, namun bisa saja mereka juga pernah menjadi saksi mata langsung tentang Yesus selama Dia masih bersama para murid dalam kesempatan tertentu maka dapat dipastikan mereka memperoleh kesaksian itu dari para murid yang pernah menjadi saksi mata langsung. Dan tentu pengalaman spiritual bersama Yesus Kristus yang akan menjadi modal berharga bagi kesaksian mereka. Sebagai contoh, Paulus yang memiliki pengalaman spiritual bersama Yesus dalam perjalanannya ke Damsyik (9:1-19). Dan yang terpenting adalah kuasa Roh Kudus yang memberi kualifikasi dan kapabilitas bagi mereka dalam bersaksi adalah modal terbesar dan yang terutama.

Tanpa peristiwa Pentakosta, maka dapat dipastikan gereja tidak akan memiliki "kuasa" untuk bersaksi. Oleh sebab itu, para saksi dapat bersaksi bagi Kristus sehingga Kerajaan Allah diberitakan dengan sempurna, maka gereja-Nya harus diberikan kuasa Roh Kudus terlebih dahulu. ${ }^{55}$ Inilah pesan yang hendak Lukas tegaskan sebagai pendahuluan dari tulisannya yang hendak mengisahkan tentang sejarah per- kembangan Kerajaan Allah melalui para saksi-Nya di dalam pimpinan dan kuasa Roh Kudus.

\section{Menjadi Saksi Kristus dari Yerusalem sampai "ke Ujung Bumi”}

Secara garis besar Yesus dalam amanat-Nya sebagaimana tercatat dalam Kisah Para Rasul 1:8 menginstruksikan bahwa kesaksian para penginjil akan dimulai dari Yerusalem, dan kemudian akan menyebar ke daerah Yudea dan Samaria, sampai ke "ujung bumi".

Bock menjelaskan demikian:

\section{${ }^{53}$ Bock, Acts, 64.}

${ }^{54}$ Matias yang terpilih sebagai pengganti Yudas Iskariot untuk melengkapi dua belas murid adalah saksi langsung dari kehidupan Yesus Kristus. Karena dia dipilih dari kriteria mereka yang selalu bersama Yesus selama Dia masih bersama para murid, yakni mulai dari baptisan Yohanes sampai Yesus terangkat ke Surga (bdg. 1:21-22) - yang waktu itu terseleksi dua orang, yakni Yusuf yang disebut Barsabas dan Matias yang akhirnya terpilih (1:23-26).

55 Andrew Brake, Menjalankan Misi Bersama Yesus: Pesan-pesan bagi Gereja dari Kisah Para Rasul (Bandung: Kalam Hidup, 2016), 4. 
Jerusalem will be important in Acts 1-7. Judea and Samaria will become a concern in Acts 8-10. After a brief return to Jerusalem in Acts 11-12, the gospel will spread, primarily focused on the mission from Antioch, eventually reaching Rome through Paul. In this sense, 1:8 introduces the book by showing a concern for the geographical expansion that Luke loves to note. ${ }^{56}$

Kisah Para Rasul 1:8 ini disejajarkan dengan nubuatan Yesaya dalam Yesaya 49:6. ${ }^{57}$ Peterson melihatnya sebagai programmatic statement dalam 1:8 tidak dapat dipahami hanya sebatas pemahaman physical geography melainkan juga dalam pemahaman theopolitical sebagaimana dalam nubuatan Yesaya tersebut dapat ditemukan tiga tahap "the new exodus" yang akan terjadi: yang pertama bahwa keselamatan pertama-tama akan turun di Yerusalem, selanjut pada tahap yang kedua akan terjadi reconstitution and reunification of Israel yang mencakup wilayah Yudea dan Samaria, dan yang terakhir bahwa keselamatan akan sampai ke "ujung bumi" sehingga bangsa-bangsa (gentiles) akan disambut ke dalam umat Allah. ${ }^{58}$

Sementara Marshall melihat programmatic statement dalam 1:8 ini sebagai sebuah cultural spread. Injil keselamatan pertama-tama akan menjangkau the Aramic-speaking Jews dan juga kelompok the Greek-speaking Hellenists di Yerusalem, dan kemudian akan meluas kepada non-Jews, yang dimulai dengan the Samaritans and the Ethiopian traveler, dan yang terakhir mejangkau bangsa-bangsa (Gentiles) yang meluas dari Kaesarea sampai ke Antiokhia, ke Siprus dan Galatia, ke Asia, ke Makedonia dan Akhaya, dan yang terakhir sampai ke Roma. ${ }^{59}$ Dengan perspektif pendekatan yang hampir sama, yakni dari sudut political-cultural, Ellis melihat 1:8, “... presents the expansion of the Christian witness from the center of Judaism to the center

${ }^{56}$ Bock, Acts, 64. Ellis membagi narasi Kisah Para Rasul berdasarkan perkembangan ekspansi penyebaran Injil secara geografis sebagai berikut: 1:1-7:60 (Yerusalem); 8:1-11:18 (Yudea and Samaria); 11:19-12:25 (Siria); 13:1-16:10 (Siprus and Asia Kecil); 16:11-19:22 (Yunani); 27:1-28:31 (Roma). Lihat Earle Ellis, "The End of the Earth' (Acts 1:8)," Bulletin for Biblical Research 1 (1991): 121.

57"Terlalu sedikit bagimu hanya untuk menjadi hamba-Ku, untuk menegakkan suku-suku Yakub dan untuk mengembalikan orang-orang Israel yang masih terpelihara. Tetapi Aku akan membuat engkau menjadi terang bagi bangsa-bangsa supaya keselamatan yang dari pada-Ku sampai ke ujung bumi" (Yes. 49:6).

${ }^{58}$ Peterson, The Acts of the Apostles, 112. Peterson mengutip pernyataan Pao dan menyetujui pernyataannya mengenai nubuatan Yesaya.

${ }^{59}$ I. Howard Marshall, New Testament Theology: Many Witnesses, One Gospel (Downers Grove, Illinois: IVP, 2004), 157-158. 
of the Roman Empire, from the mission to Palestinian Jews to the mission to Jews and Gentiles of the diaspora." 60

Dari beberapa pemahaman di atas, maka pemahaman Bock lebih sesuai dengan konteks Kisah Para Rasul. Dari catatan sejarah penyebaran Injil dalam Kisah Para Rasul, ekspansi wilayah dari l:8 lebih berkaitan dengan pemahaman geografis, yakni dimulai dari kota Yerusalem, yang merupakan kota penting secara teologis, meluas ke seluruh Yudea dan Samaria yang berbicara tentang wilayah geografis Israel secara keseluruhan, dan sampai ke "ujung bumi" dalam arti cakupan geografis bangsa-bangsa lain. Namun yang terpenting bagi Lukas catatan dalam Kisah Para Rasul 1:8 ini merupakan "a prediction and promise of the way this divine plan will be fulfilled, rather than acommand." 61

\section{Di Yerusalem (Pasal 2-7)}

Yang menjadi pertanyaan, mengapa kesaksian harus dimulai dari Yerusalem? Secara politis dan historis, Yerusalem merupakan pusat pemerintahankerajaan Israel. Di samping itu, secara kultural-religius, kota Yerusalem merupakan kota terpenting sebagai pusat kebudayaan dan religi Yudaisme. Namun alasan utama kesaksian harus dimulai dari Yerusalem ada pada alasan teologis. Secara teologis pemberian amanat untuk menjadi saksi Kristus tidak dapat dipisahkan dengan peristiwa pencurahan Roh Kudus yang akan segera terjadi di Yerusalem (1:4-5). Sebagaimana dalam pemaparan sebelumnya, para murid hanya dapat memiliki kuasa dalam bersaksi, kalau mereka telah menerima Roh Kudus. Di samping itu, pencurahan Roh Kudus dalam harapan profetik Perjanjian Lama diyakini hanya akan terjadi di Yerusalem (bdg. Yoel 2:28-32) sebagai bagian dari janji restorasi Israel (bdg. Yes. 2:2-4; Mi. 4:1-8; Zak. 8:20-23). Panggilan untuk menjadi saksi merupakan bagian dari kehidupan umat baru ketika penggenapan janji restorasi dimulai. Di Yerusalem-lah janji restorasi akan digenapi melalui pencurahan Roh Kudus. Dari sana umat lama yang mengalami restorasi menjadi umat yang baru akan menyebar untuk menyaksikan kebenaran baru tersebut serta memanggil bangsabangsa lain untuk masuk ke dalam umat yang baru tersebut.

Sebenarnya bagian ini mencakup pasal 1, tepatnya mulai 1:12. Hal ini karena pasal 1:12-26 memberi informasi bahwa para murid sudah berada di Yerusalem sesuai dengan permintaan Yesus untuk menantikan pencurahan Roh Kudus. Catatan narasi tentang bagaimana para murid tetap berada di Yerusalem ini kelihatannya secara sengaja disisipkan untuk

${ }^{60}$ Ellis, “The End of the Earth' (Acts 1:8),” Bulletin for Biblical Research 1 (1991): 121.

${ }^{61}$ Peterson, The Acts of the Apostles, 112. 
menunjukkan ketaatan para murid akan perintah Yesus agar mereka tetap berada di sana sampai pencurahan Roh Kudus terjadi (1:4-5). Bahkan Lukas memperlihatkan bahwa hampir semua pengikut Yesus Kristus ada di sana, baik sebelas murid, beberapa perempuan pengikut Yesus yang setia bersama Maria ibu Yesus, juga saudara-saudara Yesus ada di sana (bdg. 1:13-14). Di samping itu juga ada dua murid lain yang sempat disebutkan nama mereka oleh Lukasseperti Yusuf yang disebut Barsabas yang juga bernama Yustus, dan Matias rasul pengganti Yudas Iskariot (1:23). Walaupun tidak disebutkan secara eksplisit sebagaimana dalam 1:13-14 dan ayat 23, dapat dipastikan di sana juga hadir para pengikut Yesus Kristus yang setia lainnya, karana dalam 1:15 Lukas dengan jelas mencatat bahwa yang berkumpul di sana ada sekitar setarus dua puluh orang, yang oleh Lukas disebut sebagai "saudara-saudara"-nya dan Petrus (bdg. 1:15-16).

Namun, secara resmi bagian ini baru dimulai sejak terjadinya peristiwa Pentakosta (2:1-13). Peristiwa Pentakosta memiliki peran signifikan bagi teologi Lukas dalam Kisah Para Rasul. Selain sebagai catatan tentang digenapinya janji pencurahan Roh Kudus kepada orang percaya, peristiwa Pentakosta menjadi peristiwa momentum di mana tugas menjadi saksi bagi Kristus secara "resmi" di mulai. Kehadiran Roh Kudus secara supernatural ke atas rasul-rasul yang membuat mereka

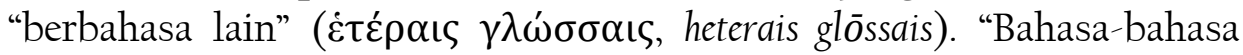
lain" di sini merujuk kepada bahasa negeri asal dari orang-orang Yahudi yang hadir pada peristiwa Pentakosta (bdg. 2:5), baik Yahudi diaspora maupun proselit, yang datang dari berbagai tempat (bdg. 2:8-12) menunjukkan penggenapan janji Yesus dalam pasal l:8 bahwa Roh Kudus yang dijanjikan yang akan memberi kuasa bagi para murid untuk bersaksi telah datang. Dengan demikian janji Bapa yang dikatakan Yesus Kristus dalam pasal 1:4-5 telah tergenapi.

Lukas memang tidak mencatat secara spesifik apakah isi dari perkataan para murid yang diucapkan dalam "bahasa-bahasa lain" yang dapat dimengerti oleh mereka yang hadir dalam masing-masing bahasa negeri asal mereka tersebut. Namun dalam ayat 1l, Lukas memberikan informasi berupa sebuah pernyataan kesimpulan bahwa apa yang dikatakan oleh para murid dalam "bahasa-bahasa lain" tersebut adalah tentang "perbuatan-perbuatan besar yang dilakukan Allah." Sekali lagi tidak ada informasi lebih detail dari Lukas, "perbuatan-perbuatan besar yang dilakukan Allah" yang bagaimana yang disaksikan oleh para rasul waktu itu. Tetapi kuasa kehadiran Roh Kudus tersebut jelas membuat sebagian dari mereka takjub (2:7-8, 12). Memang dalam ayat 12 ada kesan bahwa kehadiran kuasa dari Roh Kudus tersebut tidak sedang membuat mereka takjub kepada Allah, sebaliknya justru membuat mereka bingung, sehingga akhirnya mereka berkata kepada yang lain: "Apakah 
artinya ini?" Tidak heran ada yang berprasangka negatif akan kejadian tersebut, bahwa "Mereka [para rasul] sedang mabuk oleh anggur manis" (2:13). Peterson memberi penjelasan yang cukup baik menanggapi permasalahan ini, "This is a reminder that 'the miraculous is not self-authenticating, nor does it inevitably and uniformly convince. There must also be the preparation of the heart and the proclamation of the message if miracles are to accomplish their full purpose. This was true even for the miracle of the Spirit's coming at Pentecost."'62 Respons atas kehadiran kuasa Roh Kudus melalui perkataan para rasul dan tentu juga tanda-tanda supranatural lain yang tampak pada peristiwa Pentakosta belum dapat dinilai sampai pada ayat 13 saja. Dengan kata lain, apakah mereka sedang takjub kepada Allah atau justru kebingungan karena kejadian supranatural tersebut belum dapat ditentukan sampai pada batas ini. Peristiwa kehadiran Roh Kudus dengan tanda-tanda supranatural tersebut belumlah akhir dari pada dari tujuan kehadiran kuasa Roh Kudus untuk memberi kuasa bagi para rasul dalam bersaksi. Tanda-tanda supernatural termasuk diucapkannya "bahasa-bahasa lain" oleh para rasul lebih kepada sebuah persiapan hati mereka yang mereka yang akan menerima kesaksian para rasul. Peterson melanjutkan, "Such puzzlement and misunderstanding cried out for explanation, pointing to the need for Peter's sermon." ${ }^{63}$ Khotbah Petruslah (2:14-40) yang menjadi inti dari tugas bersaksi seorang saksi Kristus setelah menerima kuasa Roh Kudus. Tanda-tanda supernatural yang terjadi sebelumnya lebih kepada jembatan sekaligus persiapan hati bahwa Roh Kudus sedang membuka hati mereka untuk dipersiapkan dalam menerima kesaksian atau kebenaran Allah bagi mereka yang akan menerima kesaksian. Oleh sebab itu Petrus menggunakan kondisi kebingungan mereka sebagai jembatan untuk memulai khotbah/kesaksiannya (2:15). Setelah Petrus menyelesaikan kesaksiannya, sekitar tiga ribu orang ber- tobat dan memberi diri dibaptis (2:41). Walau demikian, Lukas kelihatannya mempunyai tujuan atas terjadinya "bahasa-bahasa lain" dalam peristiwa Pentakosta. Dari ayat 11 - bahwa kesimpulan dari isi perkataan para rasul yang diucapkan dalam "bahasa-bahasa lain" tersebut adalah "tentang perbuatan-perbuatan besar yang dilakukan Allah" dapat dikatakan bahwa penekanan "bahasa-bahasa lain" memiliki kaitan erat yang tidak terpisahkan dengan peranan para murid dalam bersaksi, yakni menyaksikan perbuatan-perbuatan besar Allah.

Yang menjadi pertanyaan berikut: "Mengapa para rasul harus

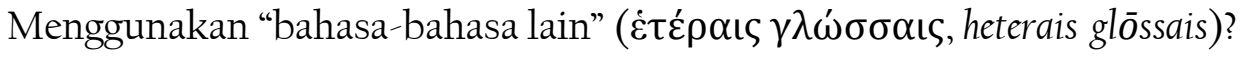

62 Peterson, The Acts of the Apostles, 138. Peterson mengutip pernyataan dari Longenecker (1981: 273).

${ }^{63}$ Peterson, The Acts of the Apostles, 138. 
Bukankah para murid dapat menggunakan bahasa Aram atau Yunani yang merupakan dua bahasa yang cukup dikenal baik secara nasional bahkan internasional ${ }^{64}$ Selanjutnya yang menjadi pertanyaan lagi, apakah para murid menggunakan berbagai bahasa? Ayat 6 dan 8 mem- beri bukti bahwa kemungkinan para murid hanya menggunakan satu bahasa, namun akhirnya oleh kuasa Roh Kudus didengar mereka yang mendengarnya dalam bahasa negeri asal mereka masing-masing. Lalu bahasa apa dan yang bagaimana yang keluar dari mulut para murid sesungguhnya? Ayat 4 sepertinya memberikan indikasi bahwa bahasa yang ucapkan para rasul adalah suatu bahasa yang bukan pada umumnya, sehingga tidak heran muncul sindiran: "Mereka sedang mabuk oleh anggur manis" (2:13). Namun di sini sulit untuk dibuktikan jenis bahasa yang bagaimana yang keluar dari mulut para rasul yang pada akhirnya didengar oleh mereka yang mendengar dalam bahasa negeri asal masing-masing. Bagaimana proses tersebut terjadi sulit untuk dijelaskan. Yang jelas itu merupakan bahasa yang diberikan oleh Roh Kudus kepada mereka untuk dikatakan (2:4). Satu-satunya jawaban yang dapat diberi- kan, sebagaimana dikatakan Bock, "God is at work." ${ }^{65}$ Kuasa Roh Kuduslah yang menjadi sebab peristiwa supranatural tersebut terjadi. Dan inilah yang dimaksud dengan tanda datangnya zaman baru atau kovenan baru. Peterson menyebutnya, "a sign that God's end-time restoration hasbegun." 66

Terkait dengan tugas sebagai saksi ada beberapa tokoh yang disebutkan Lukas dalam fase ini. Seperti rasul Petrus dan Yohanes, serta Stefanus yang merupakan satu dari tujuh diaken yang terpilih (6:1-7). Dalam 5:12-16 Lukas juga menyinggung tentang para rasul secara jamak yang melakukan banyak mukjizat dan tanda. Kelihatannya Lukas hendak memperlihatkan bahwa rasul-rasul di luar Petrus juga me- lakukan banyak mukjizat dan tanda. ${ }^{67}$

Lukas juga mencatat Petrus dan Yohanes ditangkap karena kesaksian mereka tentang kebangkitan Yesus (4:1-22). Bahkan juga dicatat narasi kamatian Stefanus karena kesaksiannya tentang Kristus (7:54-8:1a). Ini menunjukkan bagaimana serangan dan ancaman tidak mematikan semangat dan keberanian mereka untuk bersaksi bagi Kristus. Mereka tetap dengan berani dan bersemangat untuk bersaksi bagi Kristus. Tentu melalui semua itu Lukas hendak membuktikan

\footnotetext{
${ }^{64}$ Bandingkan dengan Bock, Acts, 102; dan Marshall, Acts, 70.

${ }^{65}$ Bock, Acts, 101.

${ }^{66}$ Peterson, The Acts of the Apostles, 111.

${ }^{67}$ Marshall menjelaskan, "Luke is now thinking of the healing ministry exercised not only by Peter (3:1-10) but also by the other apostles; unfortunately we have no details of the activities of the latter." Lihat I. Howard Marshall, Acts: An Introduction and Commentary, Tyndale New Testament Commentaries 5 (Nottingham, England: Inter-Varsity Press, 1980), 121.
} 
bahwa semua itu terjadi oleh kuasa Roh Kudus yang menyertai mereka dalam bersaksi.

Dalam bagian ini, Lukas juga menunjukkan bagaimana orang-orang percaya yang telah menerima atau telah dibaptis dengan Roh Kudus itu hidup dalam suatu gaya hidup yang penuh kasih (2:41-47; 4:32-37). Mereka saling memerhatikan satu sama lain, menjual dan membagibagikan harta mereka untuk membantu yang lain, bertekun dalam pengajaran rasul-rasul dan dalam persekutuan, serta bertekun dalam doa dan memecahkan roti. Sekalipun Lukas tidak mencatat bahwa mereka juga turut bersaksi bagi Kristus, namun dapat dipastikan mereka juga turut mengambil bagian dalam panggilan yang telah diamanat Kristus tersebut. Sebagaimana ditegaskan Lukas bahwa mereka disukai semua orang sehingga setiap hari Tuhan menambahkan jumlah mereka (2:47). Tentu ini sebagai hasil dari kesaksian hidup mereka yang penuh kasih, dan juga karena berkat keberanian bersaksi para "penginjil". Gaya hidup jemaat mula-mula ini merupakan suatu dampak dari hidup mereka yang dipimpin Roh Kudus. Gaya hidup demikian merupakan gambaran kehidupan komunitas umat yang baru yang tentu secara tidak langsung akan menyaksikan Yesus yang hidup dalam mereka.

Di samping itu Lukas juga memberi catatan tentang kisah Roh Tuhan menghukum mati Ananias dan Safira sebagai akibat ketidak- jujuran mereka dalam bagian ini (5:1-11). Di sini Lukas terlihat hendak menunjukkan sisi lain dari peranan Roh Kudus, sebagai Roh yang mendisiplin, yang tidak pernah kompromi dengan dosa. Secara teologis, peristiwa matinya Ananias dan Safira yang dihukum langsung oleh Roh Tuhan sesungguhnya merupakan special case. Peristiwa tersebut tidak dapat ditarik suatu kebenaran teologis yang dapat digeneralkan bagi gereja sepanjang masa. Dengan kata lain, setiap orang yang melakukan hal sama sebagaimana Ananias dan Safira akan mengalami hal yang sama, yakni langsung dihukum mati oleh Roh Tuhan. Walau demikian, memang tidak dipungkiri bahwa kasus yang sama bisa terjadi, termasuk dalam konteks gereja sekarang, yakni gereja-gereja atau zaman setelah periode Perjanjian Baru. Tetapi, sekali lagi, secara teologis, atas kasus ini tidak dapat dibangun suatu kebenaran mutlak untuk diberlakukan secara umum bagi gereja sepanjang masa sampai akhir zaman. Namun satusatunya kebenaran teologis yang dapat ditarik dari peristiwa ini adalah bahwa setiap perbuatan dosa ada konsekuensinya. Artinya Tuhan pasti akan memberi pendisiplinan bagi setiap orang yang melanggar kekudusan-Nya, termasuk orang-orang percaya. Anugerah Tuhan tidak meniadakan pendisiplinan-Nya bagi pelanggaran atau dosa. Dalam hal ini tentu sulit untuk membuat suatu daftar tentang bentuk pendisiplin- an Tuhan atas pelanggaran anak-anak-Nya. Tuhan dapat memakai segala 
secara di dalam kedaulatan-Nya untuk mendatangkan pendisiplinan, termasuk kematian seperti yang terjadi pada kasus Ananias dan Safira.

Fase ini ditutup dengan kematian Stefanus (7:54-8:1a). Kamatian Stefanus merupakan martir pertama yang mati dalam mempertahankan imannya kepada Kristus. Dengan dicatatnya narasi kematian Stefanus oleh Lukas di dalam Kisah Para Rasul yang sesungguhnya mempunyai fokus kepada memperlihatkan karya dan kuasa Roh Kudus melalui para saksi-Nya dalam menggenapi master plan Allah terkesan dilematis. Bagaimana sebagai saksi Allah yang jelas-jelas dipenuhi Roh Kudus (bdk. $6: 5,8,10 ; 7: 55)$ dapat mati dengan "tragis"? Tanpa ada pembelaan dan pertolongan Roh Kudus? Padahal sebagaimana catatan Lukas 7:55, Roh Kudus tidak meninggalkannya sampai saat dia meninggal. Kebenaran yang hendak Lukas perlihatkan melalui peristiwa ini adalah kuasa Roh Kudus yang menyertai para murid yang bersaksi lebih berfokus kepada penggenapan master plan misi Allah. Kuasa Roh Kudus berbicara tentang kedaulatan Allah dalam membuat rencana-Nya berhasil. Sehingga setiap manifestasi kuasa Roh Kudus atas para saksi-Nya selalu berkaitan dengan progres penggenapan rencana misi-Nya. Dalam hal ini, disertai kuasa Roh Kudus tidak meniadakan kemungkinan ancaman kematian bagi para saksi-Nya jikalau itu terjadi atas seizin kedaulatan-Nya dan selagi tidak menghambat progres penggenapan rencana misi-Nya. Sebaliknya, kematian Stefanus juga merupakan bagian dari rencana-Nya agar kesaksian meluas kepada fase berikutnya, yakni Yudea dan Samaria (bdg. 8:lb). Di samping itu, peristiwa kematian juga memperlihatkan keteguhan iman dan kesetiaan para saksi-Nya yang telah dikuasai oleh Roh Kudus tidak tergoyahkan bahkan oleh maut sekalipun. Bahkan 7:60 membuktikan bagaimana Stefanus memberikan satu teladan dalam meneladani Kristus secara sempurna, yakni mengampuni orang-orang yang menganiayanya sebagaimana Kristus (bdg. Luk. 23:34). ${ }^{68}$

Memang Lukas tidak memberikan gambaran cakupan rentang waktu berapa lama para "penginjil" bersaksi di Yerusalem sampai akhirnya mereka menyebar ke daerah Yudea dan Samaria seperti yang tercatat dalam 8:lb. Ancaman penganiayaan yang didahului oleh kematian Stefanus (bdg. 6:8-8:1) yang akhirnya memaksa mereka menyebar keluar dari Yerusalem. Dan tentu dapat dipastikan ini terjadi di dalam rencana Allah melalui pemimpinan Roh Kudus. Yang jelas penekanan Lukas melalui 8:lb adalah bahwa fase pertama dari panggilan untuk menjadi saksi Kristus tergenapi.

${ }^{68}$ Bandingkan dengan Andrew Brake, Menjalankan Misi Bersama Yesus, 164. 


\section{Di Yudea dan Samaria (Pasal 8-12)}

Yudea sesungguhnya merupakan sebuah sebutan orang Yunani dan Roma untuk tanah Yehuda. ${ }^{69}$ Sementara Samaria merupakan ibu kota Israel utara. ${ }^{70}$ Penyebutan ekspansi pemberitaan Injil secara geografis ke seluruh Yudea dan Samaria sesungguhnya memiliki nuansa politis. Seluruh Yudea secara politis merupakan sebutan kepada seluruh kerajaan Yehuda. Sementara Samaria mewakili seluruh kerajaan utama (Israel). ${ }^{71}$ Dalam hal ini, ketika dikatakan kesaksian tersebar ke seluruh Yudea dan Samaria, berarti secara politis itu merujuk kepada cakupan geografis seluruh kerajaan Israel dalam satu kesatuan yang mencakup kerajaan utara dan selatan. Ini juga menjadi bukti bahwa janji restorasi Israel telah terjadi, walaupun bukan dalam arti politis, melainkan spiritual, yakni Kerajaan Allah di dalam Yesus Kristus.

Lukas memperlihatkan dalam 8:1b bahwa akibat timbulnya penganiayaan yang hebat di Yerusalem, maka orang-orang percaya mulai menyebar ke seluruh Yudea dan Samaria. Seperti yang telah ditegaskan sebelumnya, bahwa melalui bagian ini secara eksplisit sepertinya Lukas hendak menunjukkan bahwa fase pertama dalam tugas bersaksi para murid telah tergenapi. Dan sekarang memasuki fase yang kedua, bersaksi di seluruh Yudea dan Samaria. Bagi Peterson ini merupakan, "A new narrative begins with a dramatic time reference." 72

Penganiayaan yang terjadi sebagai sebab perluasaan wilayah pemberitaan Injil ke seluruh Yudea dan Samaria terkesan absennya intervensi Allah melalui kehadiran Roh Kudus. Bahkan juga ada kesan orang-orang percaya mengungsi karena takut kepada penganiayaan. Lukas kelihatannya sengaja memperlihatkan bagaimana sejarah penyebaran Injil itu mengalir secara natural. Lukas sendiri tidak melaporkan adanya intervensi Roh Kudus yang secara langsung yang mengarahkan atau yang meminta orang-orang percaya untuk menyebar ke seluruh Yudea dan Samaria. Sementara di tempat lain, catatan Lukas memperlihatkan bahwa Roh Kudus dapat berintervensi mengarahkan kehidupan para saksi-Nya, misalnya ketika Paulus mendapat panggilan dari Roh Kudus yang secara dramatis mengarahkannya untuk menyeberamg ke Makedonia (16:4-12). Dengan jelasnya pimpinan dan penyertaan Roh

${ }^{69}$ J. D. Douglas, "Yudea," dalam Ensiklopedia Alkitab Masa Kini, jilid II (Jakarta: Yayasan Komunikasi Bina Kasih/OMF, 2004), 636.

${ }^{70}$ D. J. Wiseman, "Samaria," dalam Ensiklopedia Alkitab Masa Kini, jilid II (Jakarta: Yayasan Komunikasi Bina Kasih/OMF, 2004), 350.

${ }^{71}$ Kerajaan Israel setelah kematian raja Salomo terpecah menjadi dua (bdg. 1 Raj. 12:1-24), yakni kerajaan utara (Kerajaan Israel) yang dipimpim oleh Yerobeam dan kerajaan selatan (Kerajaan Yehuda) yang dipimpin oleh Rehabeam.

${ }^{72}$ Peterson, The Acts of the Apostles, 275. 
Kudus di dalam pelayanan para "penginjil" dan orang-orang percaya sebagaimana yang dipaparkan oleh Lukas dalam seluruh narasi Kisah Para Rasul, sekalipun tidak dicatat secara eksplisit, dapat dipastikan intervensi Roh Kudus ada dalam peristiwa menyebarnya orang-orang percaya ke seluruh Yudea dan Samaria, baik secara langsung maupun tidak langsung. Apalagi hal ini merupakan bagian dari master plan misi Allah seperti yang tercatat dalam 1:8, maka Roh Kudus dengan kuasa dunamis-Nya pasti mengintervensi dalam menggenapi setiap tahapan misi yang telah direncanakan Allah sendiri. Dalam hal ini dapat dikatakan, menyebarnya orang percaya keluar Yerusalem bukan karena kebetulan apalagi karena takut kepada penganiayaan yang hebat. Tetapi semuaitu merupakan progres penggenapan rencana Allah agar mereka menjadi saksi di seluruh Yudea dan Samaria. Di samping itu tentu agar mereka tetap terpelihara dari penganiayaan yang ada demi kepentingan pekerjaan Allah.

Catatan Lukas dalam 8:1b disebutkan bahwa ternyata tidak semua orang percaya keluar dari Yerusalem. Lukas dengan jelas menyebutkan bahwa para rasul masih tetap bertahan di Yerusalem. Yang menjadi pertanyaan, apakah dari sekian ribu bahkan mungkin puluhan ribu orang percaya di luar rasul-rasul semuanya keluar dari Yerusalem? Apa yang dimaksud dengan "mereka semua" dalam 8:1b? Dalam hal ini kelihatannya lebih logis kalau dikatakan tidak semua orang percaya di luar rasul-rasul yang keluar dari Yerusalem. Bock melihat bahwa "mereka semua" yang dimaksudkan di dalam bagian ini adalah orang Kristen Yunani, karena penganiayaan tersebut lebih terfokus kepada orang Kristen Yunani. ${ }^{73}$ Dalam hal ini ada tiga alasan yang dipakai dalam membangun penafsiran yang demikian: Pertama tetap tinggalnya para rasul (Kristen Yahudi) di Yerusalem membuktikan penganiayaan ke- mungkinan tidak terlalu mengancam orang Kristen Yahudi, walaupun ada namun mungkin tidak seberat yang dialami orang Kristen Yunani; kedua martir pertama dari penganiayaan tersebut adalah Stefanus yang adalah seorang Kristen Yunani; ketiga Filipus yang adalah seorang Kristen Yunani yang ikut keluar dari Yerusalem. Peterson dengan mengutip Witherington menambahkan,

There is enough evidence to conclude that the persecution was particularly directed against the Hellenists...that the apostles were exempted from the general attack on the Christians in Jerusalem 'since Acts 1-6 has stressed the great respect for these early Jewish Christian leaders among the populace of Jerusalem and the fear of them by the authorities." 74

${ }^{73}$ Bock, Acts, 318; Bock juga setuju dengan pandangan Bruse (1988a:162); Schneider (1980: 479).

${ }^{74}$ Peterson, The Acts of the Apostles, 276. 
Terkait dengan pelayanan bersaksi bagi Kristus, dalam fase ini Lukas lebih terfokus kepada Filipus (8:4-40), Petrus (9:32-11:18; 12:1-19), serta Paulus (9:1-31; 11:19-30; 12:25) dan Barnabas (11:19-30; 12:25). Juga disinggung tentang Ananias ${ }^{75}$ yang mendapat panggilan Allah untuk mendoakan Saulus (9:10-17). Dalam bagian ini Lukas juga mencatat tentang kematian Yakobus, saudara Yohanes yang dibunuh oleh Herodes (12:1-2). Hampir sama dengan fase sebelumnya, Lukas kembali memperlihatkan bahwa perjalanan narasi dari pekerjaan bersaksi para murid tetap terlihat mengalir secara natural. Seperti yang ditegaskan sebelumnya, termasuk kematiaan juga dapat terjadi atas para saksi-Nya yang telah diperlengkapi dengan kuasa Roh Kudus, karena fokus utama karya Roh Kudus bukan kepada pribadi-pribadi yang dipakai-Nya, melainkan penggenapan master plan misi Bapa.

Melalui bagian ini Lukas memperlihatkan bagaimana Roh Kudus berkarya di dalam pelayanan kesaksian para "penginjil". Memimpin Filipus dalam mengadakan banyak mukjizat dan tanda (8:6-7), memimpin Filipus untuk menjelaskan teks Yesaya 53:7-8 kepada sida- sida dari Etiopia (8:35), serta melarikannya secara supranatural dari hadapan sidasida Etiopia (8:38). Dan yang luar biasa, Lukas menunjuk-kan bagaimana Yesus sendiri menyatakan diri kepada Saulus yang adalah musuh besar bagi orang percaya waktu itu dan mengubahnya dari seorang penganiaya menjadi saksi Kristus yang efektif (9:1-19a). Dicatat juga bagaimana Roh Kudus memberi kuasa kepada Petrus menyembuh- kan Eneas dan membangkitkan Dorkas (9:32-43), memimpinnya melalui suatu penglihatan supranatural (10:9-17) untuk melayani Kornelius dan keluarganya serta membaptis mereka dengan Roh Kudus (10:44-46). Di sana Petrus mendapat pemahaman dari Tuhan bahwa pintu keselamatan telah dibuka Allah bagi bangsa-bangsa lain (gentiles). Inti dari catatancatatan tentang para saksi dalam bagian ini adalah bagaimana kuasa dan pemimpin Roh Kudus terus bekerja dalam menggenapi master plan misi Allah. Bahkan tantangan dan kematian yang dihadapi beberapa saksi Kristus tidak melemahkan iman dan semangat para saksi yang masih berkesempatan untuk bersaksi.

Lukas juga mencatat bagaimana Herodes dihukum Tuhan karena perbuatannya yang tidak menghormati Allah (12:20-23). Ini menjadi bukti bahwa tidak ada yang dapat menghalangi kuasa Roh Kudus

75 Dalam Kisah Para Rasul nama Ananias muncul dua kali dalam konteks yang berbeda, yakni dalam 5:1-6 dan 9:10-17. Ananias yang dicatat Lukas dalam 5:1-6 jelas telah meninggal karena dihukum mati oleh Roh Tuhan. Jadi, dapat dipastikan bahwa Ananias dalam 9:10-17 yang merupakan kisah dari fase Yudea dan Samaria adalah orang yang berbeda. 
bekerja dalam menggenapi rencana misi Allah, termasuk seorang yang paling berkuasa di dalam dunia ini sekalipun.

Dan yang menarik Lukas menutup fase ini dengan pernyataan, "Maka firman Tuhan makin tersebar dan makin banyak didengar orang" (12:24). Pernyataan Lukas ini secara tidak langsung hendak menegaskan bahwa misi Allah dalam fase ini telah tergenapi, dan siap untuk memasuki fase yang terakhir, "ujung bumi".

\section{Ujung Bumi (Pasal 13-28)}

Fase ini memang tidak dimulai Lukas dengan menggunakan istilah "ujung bumi" yang merujuk kepada amanat Yesus dalam 1:8 sebagaimana fase-fase sebelumnya. Untuk itu perlu didefinikan terlebih dahulu istilah

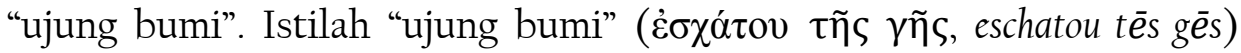
memiliki akar dalam Perjanjian Lama (bdg. Yes. 48:20; 49:6; Yer. 10:13). Namun yang menjadi pertanyaan, apakah yang dimaksud dengan "ujung bumi"? Apakah itu merujuk kepada satu lokasi tertentu secara geografis? Ataukah dalam pengertian etnik? ${ }^{76}$

Bock menjelaskan, end of the earth, "... is geographic and ethnic in scope, inclusive of all people and locales." 77 Bagi Bock, misi utama dalam fase ini memang terfokus kepada gentiles, dan Roma sendiri diyakininya sebagai its center or to the world. Namun hal ini tidak berarti misi kepada Yahudi telah berakhir sama sekali. ${ }^{78}$ Dalam menjelaskan 1:8 tentang "ujung bumi", Witherington menambahkan,

Yet it is possible to see this verse as programmatic without identifying Rome with the ends of the earth, since Acts 28 is an intentionally open-ended conclusion. It is programmatic in the sense that it alludes to a worldwide mission, and probably also to a mission to both Jew and Gentile in the Diaspora, not that it alludes to Rome. ${ }^{79}$

${ }^{76}$ Bock memperlihatkan berbagai pendekatan yang dimunculkan para ahli: “... it refers here to Spain (as in l Clem. 5.7) and thus cover the earth (Witherington 1998: 110-11), ...to Rome (of Pompey's roots in Ps. Sol. 8:15, lihat Conzelmann 1987: 7), ... Moore (1997: 389-99) has a full discussion of the issue and notes that Palestine and Ethiopia have also been suggested as options... Pao (2000: 93) also presents a full list of options, either geographic or ethnic: Is the "end of the earth" Ethiopia, Israel, Diaspora Jews, Rome, Spain, the whole world, Gentiles, or the farthest end of the earth?" Lihat Bock, Acts, 64.

${ }^{77}$ Bock, Acts, 65.

${ }^{78}$ Bock, Acts, 65.

${ }^{79}$ Witherington III, The Acts of the Apostles, 110. 
Istilah "ujung bumi" diakui tidak sedang merujuk kepada Roma. ${ }^{80}$ Lukas memang mengakhiri narasi perjalanan misi para "penginjil", khususnya Paulus di kota Roma. Namun hal ini tidak berarti misi sebagaimana diamanatkan Kristus telah selesai. Marshall melihatnya ini lebih tepat dikatakan sebagai selesainya misi dunia tahap pertama. ${ }^{81}$ Misi tahap pertama yang dimaksudkan di sini adalah misi di luar lingkup geografis Israel, yang mana Yerusalem sebagai pusat misi itu bergerak menyebar, sementara Yudea dan Samaria berfokus pada cakupan geografis Israel secara keseluruhan. Peterson juga memberikan komentar dengan nada pemahaman yang sama, "Rome is not the ultimate goal of this mission, even though Acts finishes with Paul's ministry in that city." 82 Artinya misi dunia akan terus berkesinambungan berlanjut dari generasi ke generasi, dengan cakupan geografis semakin meluas sampai memenuhi seluruh bumi dalam cakupan secara geografis. Ketika itu terjadi, maka Kristus akan datang kembali untuk kedua kalinya, yang merupakan restorasi final kerajaan "Israel" (bdg. Mat. 24:14).

Oleh sebab itu, fase ini tidak dapat hanya dipahami dalam lingkup etnik. Pintu keselamatan bagi gentiles sudah dibuka sejak pelayanan Petrus di Lida dan Yope, daerah Yudea (9:32-43) di mana Kornelius menjadi percaya. Tetapi lebih tepat dalam lingkup pemahaman geografis (di luar Israel, dalam pengertian mencakup wilayah jangkauan lebih luas di luar geografis Israel) dan etnik (dengan fokus kepada gentiles, namun tidak meniadakan lagi misi kepada Yahudi). Oleh sebab itu, dapat dikatakan secara geografis fase pertama dan kedua telah selesai penggenapannya, namun secara etnik-kultural terkait dengan misi kepada bangsa Yahudi masih akan terus berlanjut secara progresif penggenapannya sampai akhir zaman.

${ }^{80}$ Dengan menekankan kesejajaran dengan "Yerusalem" dan "Yudea dan Samaria" yang merujuk kepada suatu tempat spesifik secara geografis, Ellis melihat "the end of the earth" juga merujuk kepada suatu tempat spesifik secara geografis. Namun Ellis tidak melihat the end of the earth merujuk kepada Roma (sebagaimana narasi Kisah Para Rasul yang diakhiri dengan pelayanan Paulus di Roma), melainkan kepada Spanyol, sebagaimana kota tujuan akhir dari perjalanan misi Paulus (bdk. Rom. 15:24, 28). Karena diperkirakan Kisah Para Rasul ditulis Lukas pada masa penganiayaan Nero (65-

68 AD.), maka demi menjaga keselamatan Paulus dan juga hakim Roma yang membebaskan Paulus, maka Lukas tidak menyebut secara spesifik kota Spanyol yang merupakan kota tujuan akhir dari perjalanan misi Paulus. Bagi Ellis catatan Lukas 26:32 memberi indikasi optimis bahwa Paulus dibebaskan, sehingga dapat melanjutkan perjalanan misinya sampai ke Spanyol. Lihat Ellis, "The End of the Earth' (Acts 1:8),"

Bulletin for Biblical Research 1 (1991):131-132.

${ }^{81}$ Marshall, TheActs of The Apostles, 61.

82 Peterson, The Acts of the Apostles, 112. 
Perintah Roh Kudus dalam 13:2 agar mengkhususkan Barnabas dan Saulus bagi tugas yang telah ditentukan Tuhan bagi mereka menjadi bukti penanda dari Tuhan bahwa kesaksian para murid telah memasuki fase baru. Di samping itu penyebutan beberapa nama tempat seperti Antiokhia, Seleukia, Siprus, secara geografis merujuk kepada wilayah di luar teritorial Israel. ${ }^{83}$ Dengan demikian secara geografis, mulai pasal 13 kesaksian para murid telah memasuki fase terakhir, "ujung bumi."

Fase ini Lukas mulai dengan perjalanan misi Paulus bersama Barnabas (13:4). Di sini fokus Lukas kelihatannya mulai beralih dari Petrus kepada Paulus. Paulus penting bagi Lukas karena dia dipakai oleh Allah sebagai pioner bagi pelayanan yang meluas kepada gentiles. Pelayanan Petrus kepada Kornelius dan keluarga memang menunjukkan bahwa Petrus juga dipakai Tuhan untuk bersaksi kepada gentiles (10:1- 48), namun Petrus tidak dipanggil secara spesifik ke dalam pelayanan tersebut. Panggilan kepada Petrus untuk melayani Kornelius dan keluarganya lebih kepada penegasan Allah bahwa keselamatan juga dibutuhkan oleh bangsa-bangsa lain (gentiles), misi penebusan Allah juga tertuju kepada bangsa-bangsa di luar Israel (10:45; 11:1-18). Hal ini diteguhkan melalui penglihatan yang Petrus dapatkan dari Tuhan (10:10- 17; bdg. 11:5-10). Berbeda dengan Paulus, dalam 9:15 sebagaimana dicatat Lukas, Tuhan secara khusus menegaskan bahwa Paulus adalah alat pilihan Tuhan untuk "bangsabangsa lain". Sekalipun Tuhan juga katakan bahwa Paulus juga dipakai untuk memberitakan nama Tuhan kepada raja-raja dan orang-orang Israel. Namun tugas pertama Paulus adalah membawa Injil kepada "bangsa-bangsa lain". Dalam hal ini, dengan menyoroti pelayanan Paulus, khususnya melalui perjalanan misi Paulus, Lukas membuktikan bahwa kesaksian tentang Kristus telah memasuki fase "ujung bumi". ${ }^{84}$ Yang akhirnya Paulus akhiri perjalanannya di kota Roma, yang merupakan kota yang menjadi pusat berkumpulnya bangsa-bangsa pada waktu itu, yang oleh Bock disebut sebagai "center or to the world." ${ }^{85}$

Selain Paulus, dalam fase ini Lukas juga mencatat pelayanan beberapa tokoh "penginjil" lainnya, seperti Barnabas, Timotius, Yohanes Markus, Silas, Apolos, termasuk sang penulis sendiri, Lukas, disebutkan sebagai rekan perjalanan misi Paulus. Namun pelayanan tokoh-tokoh yang lain tidak terlalu menonjol dalam catatan Lukas. Perhatian utama Lukas adalah perjalanan misi Paulus.

\footnotetext{
${ }^{83}$ Lihat Bock, Acts, 64. Bandingkan dengan Marshall, New testament Theology, 157.

${ }^{84}$ Carson dan Moo, An Introduction to the New Testament, 288.

${ }^{85}$ Bandingkan dengan Bock, Acts, 65.
} 
Sekalipun berfokus kepada pelayanan misi Paulus, perhatian Lukas kepada peranan Roh Kudus tetap sangat terlihat. Bahkan Lukas secara eksplisit menunjukkan bahwa perjalanan misi yang Paulus lakukan merupakan perintah Roh Kudus (bdg. 13:2, 4). Hal ini menjadi dasar pemahaman bahwa Roh Kuduslah yang memimpin langkah perjalanan misi Paulus. Pengalaman Paulus dalam panggilan pelayanannya ke Makedonia menjadi bukti bahwa intervensi Roh Kudus ada dalam perjalanan pelayanan Paulus (bdg. 16:4-12). Di dalam kekuatan kuasa Roh Kudus, Paulus terlihat bersaksi dengan penuh keberanian, sekalipun harus berhadapan dengan ancaman penjara bahkan kematian.

\section{Implementasi Teologis Kisah Para Rasul 1:8 dan Penggenapannya dalam Pelayanan Misi Gereja Masa Kini}

Kisah Para Rasul 1:8 dan penggenapan progresifnya di atas dapat dibangun beberapa kebenaran teologis sebagai implementasi ke dalam pelayanan misi gereja masa kini:

\section{Misi adalah Master Plan Karya Penebusan Allah}

Kisah Para Rasul 1:8 membuktikan pekerjaan misi sebenarnya berbicara tentang master planAllah dalam menyelamatkan umat manusia dari kebinasaan yang merupakan akibat kejatuhan manusia ke dalam dosa (bdg. Rom. 3:23; 6:23). Witherington melihat 1:8 berisi "God's salvation plan." ${ }^{86}$ Bahkan Alkitab secara keseluruhan memberikan suatu gambaran akan sebuah narasi besar dari sejarah karya penyelamatan Allah sepanjang sejarah umat manusia hingga akhir zaman. Dalam Per-janjian Lama sejak kejatuhan Adam dan Hawa, Allah telah mem- proklamirkan master plan misi penebusan-Nya bagi manusia yang telah jatuh ke dalam dosa tersebut (bdg. Kej. 3:15). ${ }^{87}$ Sejak itu Allah mulai

${ }^{86}$ Bandingkan dengan Witherington III, The Acts of the Apostles, 111.

${ }^{87}$ Kejadian 3:15 dikenal sebagai protevangelium (Injil pertama), yakni kabar baik tentang kemenangan yang akan terjadi bagi keturunan Adam dan Hawa atas si ular (Setan) - bandingkan dengan Derek Kidner, Genesis: An Introduction and Commentary, Tyndale Old Testament Commentaries 1 (Nottingham, England: Inter-Varsity Press, 1967), 75. Ayat ini mengandung nilai profetik yang merujuk kepada kedatangan Mesias. Hamilton, walaupun tidak terlalu setuju melihat ayat hanya semata sebuah messianic prophecy - lihat Victor P. Hamilton, The Book of Genesis. Chapters 1-17, The New International Commentary on the Old Testament (Grand Rapids, MI: Wm. B. Eerdmans Publishing Co., 1990), 199 - namun dia tidak memungkiri messianic prophecy yang terkandung di dalamnya. Hal ini terlihat dari pengakuan Hamilton, "Would this individual, or these individuals, be among the kings of Israel and Judah who are the "offspring" of their father (2 Sam. 7:12; Ps. 89:5 [Eng. 4]), who "crush" their enemies (Ps. 89:24 [Eng. 23]) "under their feet" 
menjalankan misi penebusan-Nya, termasuk kepada Adam dan Hawa yang baru saja jatuh ke dalam dosa waktu itu. Hal ini terlihat dari tindakan Allah membuatkan pakaian dari kulit binatang kepada mereka (bdg. Kej. 3:20). Penggunaan kulit sebagai sebagai pakaian mengandung makna simbolik tentang penebusan. ${ }^{88}$ Sementara narasi Perjanjian Baru berfokus pada realisasi janji mesianik dari PL tersebut, yakni narasi tentang kedatangan Mesias (terfokus dalam empat Injil dan juga dalam beberapa bagian dari kitab-kitab lain dalam PB) dan pasca kedatangan Mesias (mulai dari Kisah Para Rasul sampai Yudas, termasuk Wahyu), serta realisasi final dari karya penebusan Allah pada akhir zaman nanti (terfokus pada Wahyu juga beberapa bagian dari kitab-kitab PB lainnya). Secara konklusif, dapat disimpulkan bahwa seluruh narasi Alkitab mulai dari Kejadian sampai dengan Wahyu memperlihat sebuah metanarasi dari karya penebusan Allah yang merupakan master plan misi Allah. Narasi Alkitab membuktikan, Allah sendirilah yang menjadi Perancang sekaligus Pemilik dari master plan misi yang akan dijalankan oleh para saksi-Nya di dunia.

Hal ini mengingatkan gereja dalam merancang suatu program pelayanan misi bahwa langkah pertama yang harus dilakukan oleh gereja adalah mencari master plan misi Allah. Master plan yang dimaksudkan di sini adalah rencana atau kehendak Tuhan sendiri atas suatu misi yang akan dijalankan oleh gereja-gereja-Nya. Di mata Tuhan, belum tentu segala yang baik adalah kehendak atau rencana Tuhan. Para murid dapat saja melakukan tugas mereka sebagai saksi di luar master plan Allah dari Kisah Para Rasul 1:8, misalnya dengan langsung berangkat ke Mesir untuk bersaksi di sana. Di mata manusia hal itu kelihatannya tidak bertolak belakang dengan kehendak Tuhan. Namun sesungguhnya di mata Tuhan itu tidak sesuai dengan apa yang menjadi master plan Allah. Kalau itu tidak sesuai dengan master plan Allah, berarti gereja sedang menjalankan master plan-nya sendiri. Kalau yang dijalankan adalah master plan sendiri, maka gereja sedang tidak melakukan kehendak Allah. Narasi sejarah penyelamatan Allah dalam Alkitab termasuk narasi para saksi dalam Kisah Para Rasul membuktikan, tidak ada saksi-Nya yang tidak

(2 Sam. 22:39), so that these enemies "lick the dust" (Ps. 72:9)? Later revelations will state that it is Jesus who reigns until he puts all his enemies under his feet (1 Cor. 15:25). - lihat Hamilton, The Book of Genesis. Chapters 1-17, 200.

${ }^{88}$ Tindakan Allah yang memberikan pakaian sebagai penutup ketelanjangan mengambarkan tindakan Allah memberikan keselamatan kepada Adam dan Hawa yang telah jatuh ke dalam dosa. Di samping itu penggunaan kulit binatang melambangkan sebuah tindakan pengorbanan yang berdarah yaitu menggunakan binatang dan darah. Diyakini ini yang akhirnya menjadi sistem kurban dalam Perjanjian Lama. Bandingkan dengan Hamilton, The Book of Genesis. Chapters 1-17, 207. 
dipanggil dan diutus oleh Allah sendiri. Panggilan dan pengutusan oleh Allah merupakan tindakan pendelegasian master plan misi Allah kepada para saksi-Nya untuk dilaksanakan. Gereja yang menjalankan misi masa kini juga harus mendapatkan master plan misi Allah, karena dengan demikian membuktikan gereja tersebut dipanggil dan diutus secara khusus oleh Allah untuk melakukan suatu misi khusus.

Alasan utama mengapa gereja perlu menyesuaikan program misi dengan master plan misi Allah adalah karena Allah di dalam Kemahatahuan-Nya mengetahui tempat yang paling membutuhkan Injil-Nya; siapakah orang-orang yang telah dipilih dalam kekekalan-Nya untuk diselamatkan; dan cara yang paling tepat supaya Injil-Nya dapat disaksikan secara efektif. Dengan demikian pada akhirnya, misi yang dikerjakan suatu gereja akan memberikan hasil yang maksimal, karena yang dilakukan bukan master plan pribadi, melainkan Allah.

Dasar yang diperlukan supaya gereja (pribadi) dapat menangkap master plan Allah adalah: 89

1. Kedekatan relasi dengan Allah.

2. Kemurnian dan ketulusan hati dalam mencari kehendak-Nya.

3. Ketekunan dalam mencari kehendak-Nya.

4. Jadikan firman Tuhan dasar dalam memberi pertimbangan.

5. Juga diperlukan hikmat Tuhan dalam memberi pertimbangan.

\section{Roh Kudus sebagai Suksesor Misi Allah}

Lukas melalui Kisah Para Rasul membuktikan bagaimana seluruh master planmisi Allah yang diamanatkan kepada para murid-Nya sukses terlaksana secara progresif. Namun, sebagaimana telah dijelaskan sebelumnya, Lukas menunjukkan kesuksesan terlaksananya program misi Allah itu bukan karena kehebatan para saksi, tetapi Roh Kuduslah suksesor dibalik semua kesuksesan tersebut. Karena misi yang dilakukan gereja adalah master plan Allah, maka yang paling mengerti bagaimana menyukseskan master plan misi Allah adalah Allah sendiri melalui Roh Kudus. Melalui narasi Kisah Para Rasul, Lukas memperlihatkan bagaimana "Roh Kudus mengarahkan karya misi gereja mula-mula, seperti dalam tindakan gereja Antiokhia (13:2) dan larangan yang menghalangi Paulus dan para rekannya memasuki Bitinia (16:7)."90 Hal ini membuktikan intervensi karya atau peran Roh Kudus penting dalam suatu program misi Allah. Sebagaimana telah ditegaskan sebelumnya,

\footnotetext{
${ }^{89}$ Dalam hal ini masing-masing pribadi sebagai tim perumus program misi gereja harus memiliki dasar ini.

${ }^{90}$ Donald Guthrie, Pengantar Perjanjian Lama, vol. 1 (Surabaya: Momentum, 2010), 324.
} 
penggenapan ketiga fase rencana misi Allah secara progresif, sekalipun terlihat mengalir atau berjalan secara natural, namun aktor utama dibalik semua itu adalah Roh Kudus.

Oleh sebab itu, sebagaimana para saksi Kristus yang pertama, hal pertama yang perlu dimiliki oleh gereja - orang-orang yang akan pergi bermisi - harus dipastikan benar-benar telah "dibaptis" oleh Roh Kudus. Dengan kata lain, sungguh-sungguh telah percaya dan menerima Yesus Kristus sebagai Tuhan dan Juruselamat, sehingga memungkinkan Roh Kudus ada dan bekerja di dalam diri mereka. Ketika seorang pelaksana misi mengandalkan Roh Kudus dalam menjalankan misi: dia akan dipimpin oleh Roh Kudus ke jalan dan cara yang tepat - yang sesuai rencana Allah - dalam menjalankan misi Allah.

\section{Misi adalah Menjadi Saksi Kristus}

Kisah Para Rasul 1:8 mengingatkan bahwa bermisi adalah menjadi saksi bagi Kristus. Dengan kata lain, setiap program misi yang dijalankan gereja harus berujung pada memperkenalkan Kristus. Misi yang sejati hanyalah menjadi saksi bagi Kristus. Dengan demikian tidak alasan bagi gereja atau orang Kristen tertentu secara pribadi untuk tidak menjadi saksi Kristus. Dengan kata lain, seluruh gereja Tuhan baik secara pribadi maupun komunal atau organisasi, harus bermisi bagi Allah. Dalam hal ini modal yang diperlukan gereja dalam bermisi bukanlah masalah dana atau uang atau materi penunjang misi lainnya, tetapi hati yang rela untuk taat kepada tuntunan Roh Kudus untuk pergi menjadi saksi Kristus.

\section{Misi Gereja adalah Lanjutan dari Fase "Ujung Bumi”}

Pola tahapan bersaksi dalam Kisah Para Rasul 1:8 ini seringkali dipakai sebagai pola bagi gereja dalam bermisi. Mereka mengalegoriskan tahapan tersebut sebagai suatu pola dalam bermisi masa kini dalam konteks yang berbeda-beda. Dengan kata lain, misi harus dimulai dari lingkungan terdekat kita (Yerusalem), setelah itu baru meluas kepada lingkup yang lebih jauh, seperti keluarga besar kita (Yudea dan Samaria), setelah itu baru kepada orang-orang di luar keluarga kita, orang lain (ujung bumi). Yang menjadi pertanyaan, apakah secara teologis pola ini masih berlaku dalam pelayanan misi sekarang?

Secara teologis tahapan-tahapan master plan misi Allah dalam Kisah Para Rasul 1:8 tidak dapat lagi diaplikasikan kepada konteks misi gereja masa kini. Ada dua alasan mengapa tahapan-tahapan tersebut tidak dapat dipakai secara literar bagi konteks misi sekarang adalah bahwa apa yang telah amanatkan oleh Yesus Kristus kepada pada murid tersebut merupakan peristiwa momentum pergerakan misi dari umat kovenan lama yang telah direstorasi menjadi umat kovenan baru. Yang secara teologis - sebagaimana dalam penjelasan sebelumnya - memang 
hanya akan dimulai dari Yerusalem, yang merupakan pusat ibadah umat Israel kepada Allah - karena Bait Allah ada di sana - menyebar ke seluruh Yudea dan Samaria - dalam cakupan wilayah Israel secara keseluruhan dan yang terakhir baru menjangkau wilayah geografis bangsa-bangsa lain. Secara geografis fase pertama dan kedua telah selesai penggenapannya, namun secara etnik-kultural khususnya dalam konteks misi kepada orang Yahudi dapat dikatakan akan terus berlanjut secara progresif hingga saat ini bahkan sampai kepada kedatangan Kristus kedua kali pada akhir zaman.

Sementara tahap "ujung bumi" seperti yang dicatat Lukas dalam Kisah Para Rasul penggenapannya belum bersifat final. Dan misi dunia ini akan terus meluas secara berkesinambungan berlanjut dari masa ke masa, dengan cakupan geografis semakin meluas sampai memenuhi seluruh bumi dalam cakupan secara geografis. Pelayanan misi yang dijalankan gereja atau anak Tuhan secara pribadi masa kini adalah lanjutan progresif dari fase "ujung bumi" tersebut. Tugas misi gereja sekarang adalah fasa dari membawa Injil agar sampai ke seluruh bumi, yang mencakup dunia/bangsa keseluruhan secara geografis dan etnis.

\section{Kesimpulan}

Kisah Para Rasul 1:8 merupakan suatu master plan misi Allah yang Kristus amanatkan kepada para murid. Melalui pertolongan dan kuasa Roh Kudus yang telah dicurahkan para peristiwa Pentakosta, seluruh master plan misi Allah tersebut tergenapi secara progresif. Itulah yang hendak Lukas perlihatkan melalui kitabnya yang kedua, Kisah Para Rasul.Kebenaran ini menjadi landasan pemahaman teologis bahwa bermisi adalah melaksanakan master plan misi Allah.

Secara keseluruhan kitab Kisah Para Rasul memperlihatkan bagaimana Roh Kudus berkarya mengenapi seluruh master plan misi Allah dalam 1:8 melalui para saksi-Nya secara progresif. Dalam hal ini Roh Kudus memimpin mereka, memampukan mereka, serta memperlengkapi mereka dengan kuasa agar para saksi dapat menjalankan tugas mereka secara efektif. Kebenaran ini memberikan suatu prinsip dasar dalam bermisi, yakni menjadikan Roh Kudus sebagai Suksesor keberhasilan suatu program misi. Dengan kata lain mengandalkan pimpinan dan kekuatan Roh Kudus dalam bermisi atau bersaksi.

Kisah Para Rasul memberikan suatu dasar kebenaran bahwa pelayanan misi yang dilakukan gereja-gereja sekarang sesungguhnya merupakan kelanjutan dari fase "ujung bumi." Misi yang dilakukan oleh gereja-gereja masa kini adalah bagian dari fase memperkenalkan Kristus sampai ke seluruh permukaan bumi secara geografis hingga Kristus kembali untuk kedua kalinya pada akhir zaman. 


\section{Kepustakaan}

Barrett, C. K. A Critical and Exegetical Commentary on the Acts of the Apostle: In Two Volumes. Edinburgh: T\&T Clark International - The International critical commentary on the Holy Scriptures of the Old and New Testament, 2004.

Black, David Alan and David S. Ed. Interpreting the New Testament: Essays on Methods and Issues. Nashville, Tennessee: Broadman \& Holman Publishers, 2001.

Bock, Darrell L. Acts. Baker Exegetical Commentary on the New Testament. Grand Rapids, MI: Baker Academic, 2007.

Brake, Andrew. Menjalankan Misi Bersama Yesus: Pesan-pesan bagi Gereja dari Kisah Para Rasul. Bandung: Kalam Hidup, 2016.

Bruce, F. F. The Book of the Acts. The New International Commentary on the New Testament. Grand Rapids, MI: Wm. B. Eerdmans Publishing Co., 1988.

Carson, D. A. dan Douglas J. Moo. An Introduction to the New Testament Second Edition. Grand Rapids, Michigan: Zondervan, 2005.

Douglas, J. D. Ed. Ensiklopedia Alkitab Masa Kini. Jilid II. Jakarta: Yayasan Komunikasi Bina Kasih/OMF, 2004.

Drane, John. Memahami Perjanjian Baru: Pengantar Historis-Teologis. Jakarta: BPK Gunung Mulia, 2005.

Ellis, E. Earle. “The End of the Earth' (Acts 1:8).” Bulletin for Biblical Research 1 (1991): 123-132.

Goldsworthy, Graeme. "The Kingdom of God as Hermeneutic Grid," Southern Baptist Journal of Theology 12:1 (Spring 2008): 4-15.

Guthrie, Donald. Pengantar Perjanjian Lama. Vol. 1. Surabaya: Momentum, 2010.

Hamilton, Victor P. The Book of Genesis. Chapters 1-17 The New International Commentary on the Old Testament. Grand Rapids, MI: Wm. B. Eerdmans Publishing Co., 1990.

Kidner, Derek. Genesis: An Introduction and Commentary. Tyndale Old Testament Commentaries 1. Nottingham, England: Inter-Varsity Press, 1967.

Klein, William W. Craig L. Blomberg, Robert L. Hubbard, Jr. Introduction to Biblical Interpretation 2: Pengantar Tafsiran Alkitab. Malang: SAAT, 2013.

Marshall, I. Howard. New testament Theology: Many Witnesses, One Gospel. Downers Grove, Illinois: IVP, 2004.

Marshall, I. Howard. The Acts of The Apostles: An Introduction and Commentary. Tyndale New Testament Commentaries. Nottingham \& Surabaya: Inter-Varsity Press \& $\&$ Momentum, 2007. 
Miles, Todd L. "A Kingdom without a King? Evaluating the Kingdom Ethic(s) of the Emerging Church," Southern Baptist Journal of Theology 12:1 (Spring 2008): 88-103.

Peterson, David G. The Acts of the Apostles The Pillar New Testament Commentary. Grand Rapids, MI; Nottingham, England: William B. Eerdmans Publishing Company, 2009.

Witherington III, Ben. The Acts of the Apostles: A Socio-Rhetorical Commentary. Grand Rapids, MI: Wm. B. Eerdmans Publishing Co., 1998. 